Historic, Archive Document

Do not assume content reflects current scientific knowledge, policies, or practices. 



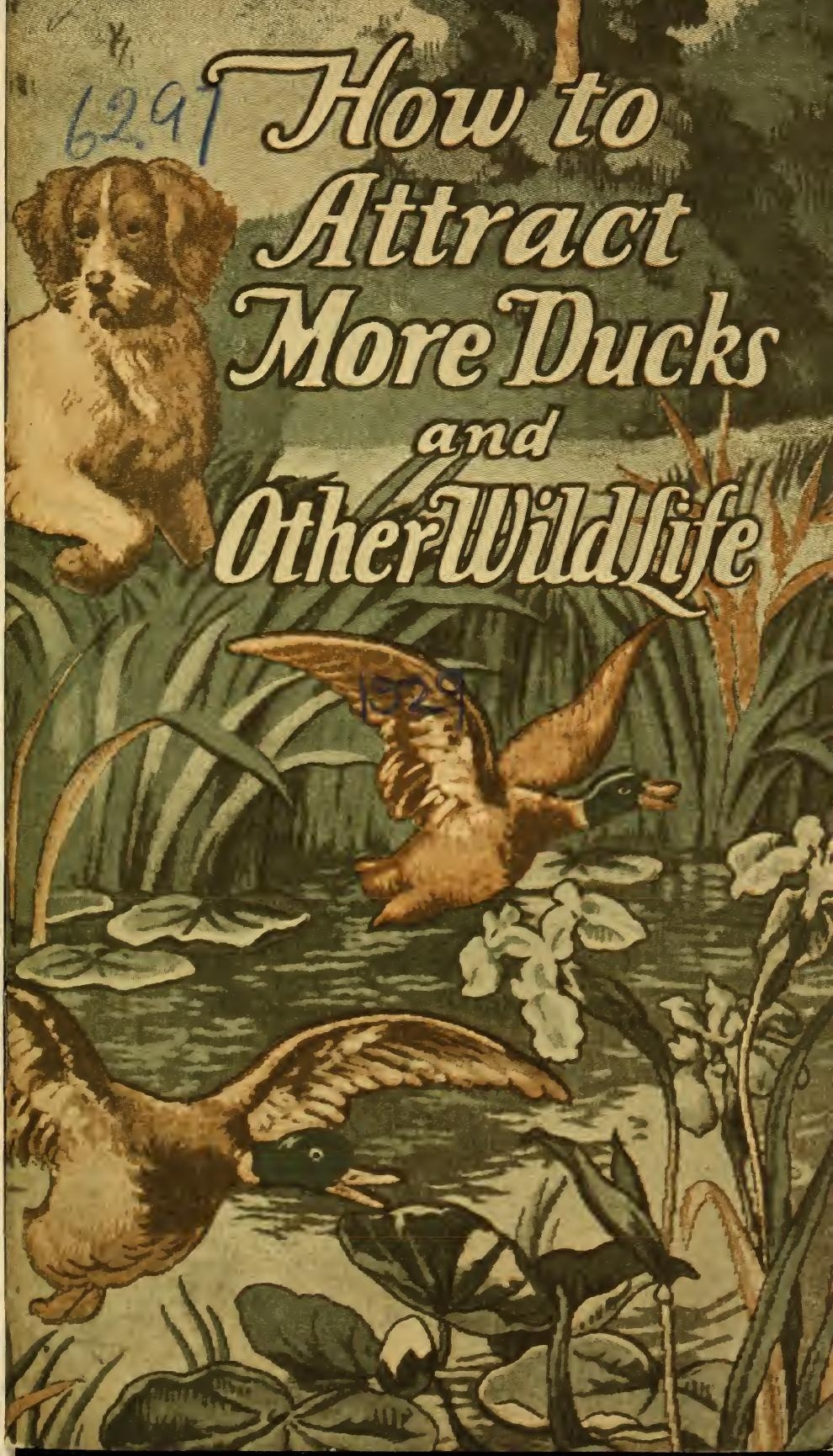




\section{INDEX}

Foods For

Ducks ........................ 1 to 7,9 to 19

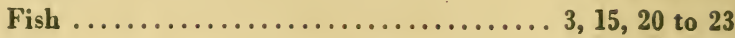

Men .......................... 8, 15, 16, 17

Muskrats $\ldots . \ldots \ldots \ldots \ldots \ldots \ldots \ldots \ldots \ldots \ldots \ldots$. 7

Prairie Chickens $\ldots \ldots \ldots \ldots \ldots \ldots \ldots \ldots \ldots \ldots . \ldots 18$

Quail ............................. 3,16 to 18

Ruffed Grouse $\ldots \ldots \ldots \ldots \ldots \ldots \ldots \ldots \ldots . \ldots 16$ to 18

Song Birds $\ldots \ldots \ldots \ldots \ldots \ldots \ldots \ldots \ldots, 16,17,18$

Ornamental,

Plants $\ldots \ldots \ldots \ldots \ldots \ldots \ldots \ldots \ldots \ldots . \ldots \ldots$ to $6,11,15,19$

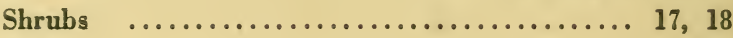

Vines .................................... 16

Plantings Carried Out $\ldots . . \ldots \ldots \ldots \ldots \ldots \ldots \ldots \ldots . \ldots 24$

Planting Plans and Investigations of Waters Made ...... 24

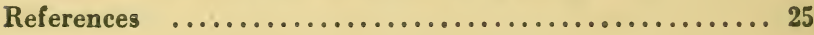

WILD Rice

Seed for Planting $\ldots \ldots \ldots \ldots \ldots \ldots \ldots \ldots \ldots, 2$ to 7

For Table Use $\ldots \ldots \ldots \ldots \ldots \ldots \ldots \ldots \ldots \ldots \ldots, 8$

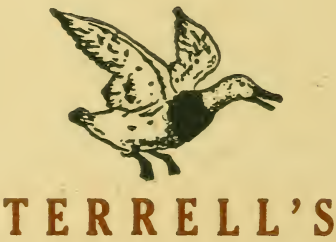

AQUATIC FARMS AND NURSERIES

Oshkosh, Wisconsin, U. S. A. 

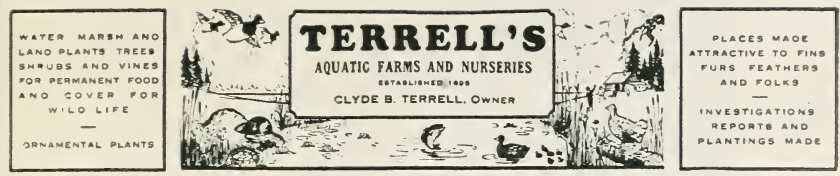

Oshkosh, Wisconsin. U. 8. A.

Dear Fellow Outdoors-man:-

Have you some favorite bit of water or marsh that you would like to make an ideal feeding and stopping place for wild ducks?

The ducks will soon come dom from the North. Will they stop with you for several weeks, or just get a drink and be on their way - - or pass you by altogether? This depends largely on whether they find plenty of theis faporite food. Ducks naturally stop at the best feeding places for the same reason that you pass up a poor restaliant for a good one.

Tre have a limited supply of the seeds of Tild Rice and other favorite foods thst ducks fly hundreds of miles to find, ready for lmmediate shipwent. This is Nature's sowing sesson - the ldeal time for planting. Your increased enjoyment and the greater value of your proderty resulting from having more ducks, will repay many times the small investment in seed. These natural foods reseed year after year, so are much cheaper than baiting rith grain.

From making plantings of duck foods throughout the country for the past 33 years, under a wide varlety of conditions, we have learned just bow these plantings should be made to insure success. To help you get the best results from your planting, I am presenting you with this little booklet. It has our long experience back of 1 t.

You may mark orces on atrached urder blank.

Yours for more 1110 ducks,

CB?:AP
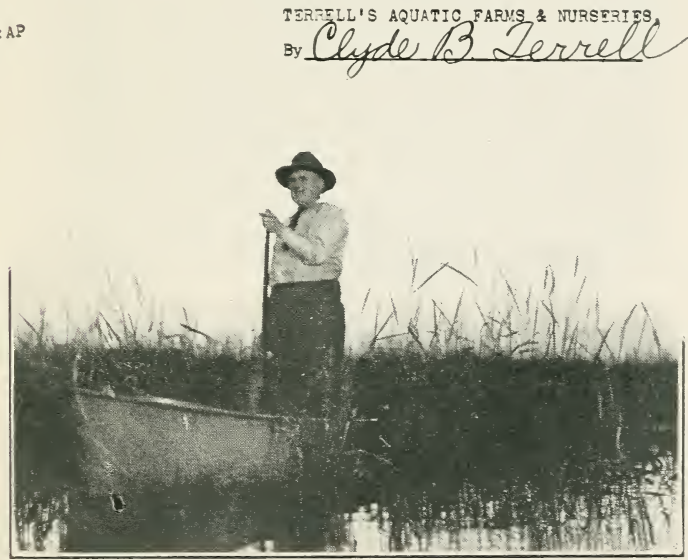

Clyde B. Terrell, Specialist on Development Of Attractive Places for Birds, Game and Fish 


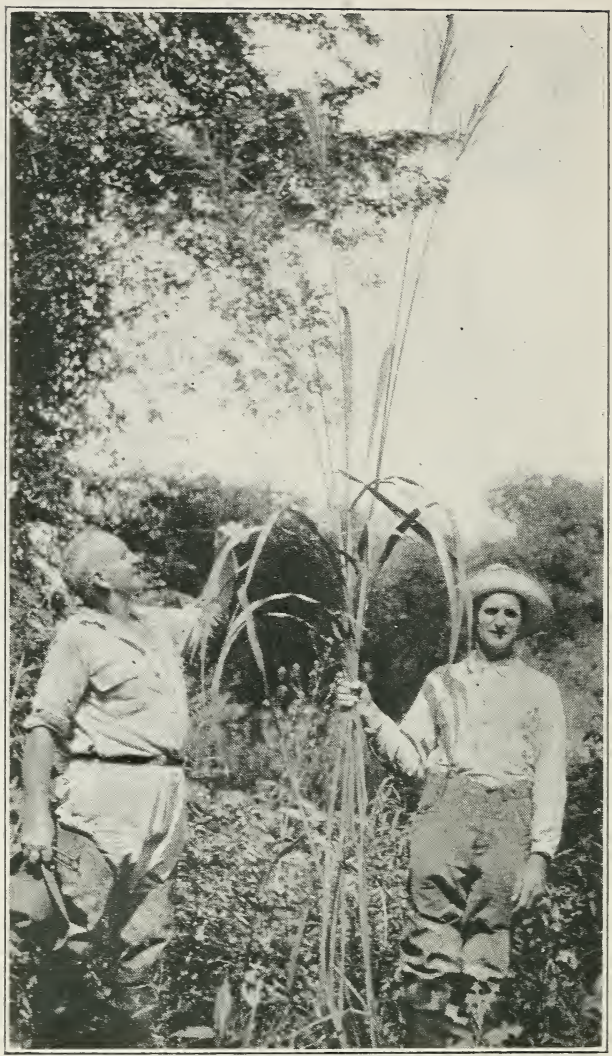

Grown From Terrell's Giant Wild Rice Seed

"Our Wild Rice in Spring Hole at our club preserve has reached the phenomenal height of fourteen feet. Can you beat it and where? We have proofs in photographs."-Writes J. G. Reul, member of the Woodlawn Gun Club, Marshall County, Illinois. The photo above shows their Wild Rice, 14 feet high, grown from TERRELL'S GIANT WILD RICE SEED. Can you imagine what a wonderful feeding ground and excellent cover for ducks is provided by a bed of this Wild Rice? 


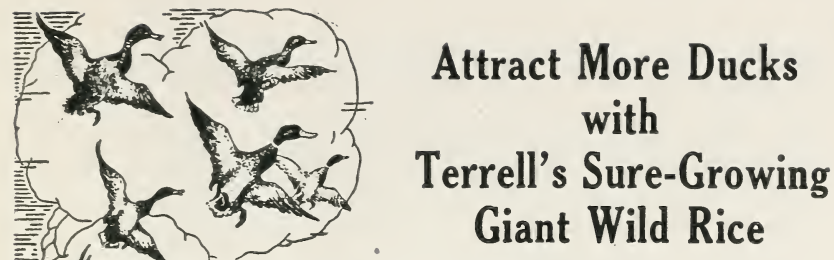

W HERE Wild Rice ( Zizania Aquatica) grows you are sure to find wild ducks swarming in to feed on this large nutritious grain. It is the best known and most important food for Mallards, Black Ducks, Widgeons, Teal, Pintails, Canada Geese and other wildfowl. Wild Rice beds are also used by the ducks in the spring as a place to hide their nests and rear their ducklings.

U. S. Biological Survey Bulletin No. 21 reports Wild Rice to be eaten by Quail and says, it also furnishes desirable cover for them. Muskellonge, Black Bass and other fish hang around Wild Rice beds.

Wild Rice reseeds itself from year to year making a permanent feeding ground.

\section{WHERE TO PLANT}

Terrell's Giant Wild Rice is easy to grow. There are many places throughout the U. S. and Canada where it does not now grow, where conditions are favorable for growing it. Briefly stated the conditions required for successful growth of Wild Rice are fresh water streams, lakes or ponds having an outlet, fairly rich bottom, and water from 6 inches to 3 feet in depth. Sunny sheltered bays or coves where planting will not get the full current or direct wash of waves, suit it best. Wild Rice thrives in either slightly sour (acid) water as is commonly found in swamps, or in moderately alkaline waters containing lime or marl. It grows best north of a line drawn from Savannah, Georgia to San Francisco, California, although occasionally grown further south.

\section{SALT WATER LIMITS}

Wild Rice does not grow in water salty to taste. Near the sea-coast it grows along streams twenty to fifty miles above the point where they enter the sea, where the water ceases to be salty to taste and there is not over four feet of tide. Any spots where fresh water brooks or snring enter such streams will be more fresh and better for Wild Rice.

\section{GROWS WELL IN OLD TAME RICE FIELDS}

Many tame rice fields found in Southeastern U. S. depending upon tides for water supply, provide suitable conditions for growing Wild Rice. On many of these old rice fields the banks are broken, allowing the free change of water that Wild Rice requires. If the banks are not broken one or more gates in the levee banks can be left open. Many sportsmen owning plantations having these old rice fields are developing splendid stopping and feeding grounds for wild ducks. We have personally investigated and planted some of these properties. 


\section{How Terrell Produces Better Wild Rice Seed}

]. Seed selected for large size grain. It is more than twice 1. the size of other Wild Rice seed. One acre of Terrell's Giant Wild Rice No. 1 will produce as much food as two acres of the kind having the ordinary smaller grain (No. 2).

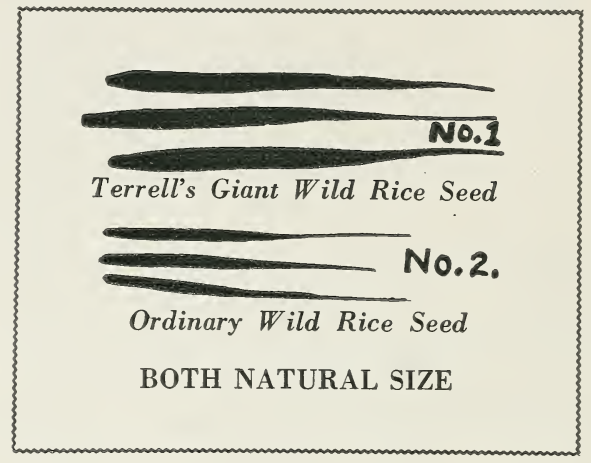

2. Terrell's supply only sure-growing Wild Rice Seed. Unripe, dried out or heated Wild Rice seed grows poorly or not at all. It is natural for the seed to drop off into the water when ripe. Drying kills the seed. Terrell's sure-growing Wild Rice seed is well-ripened. Heating and drying out are prevented by keeping the seed packed in our special damp cold storage.

3. Great care is taken to insure the seed reaching its des3. tination in highly germinable condition. Ice is placed in the center of each package of seed, if the shipment is to encounter warm weather. Shipments are packed damp and cool in special ventilated packages, surrounded by a particular kind of moss that will retain moisture, preserve the ice and keep the shipment cool for many days. Terrell's Giant Wild Rice seed has been succeessfully shipped to and grown in distant lands, such as New Zealand, Sweden and Ireland. This shows that with Terrell's special methods of packing, these perishable seeds can be successfully shipped almost anywhere. 
NI. Clyde B. Terrell,

Oskiosh, His., U. S. A.

Dear Sir:-

You $\$ 111$ be pleased to hear that we bave at last been successful in acclimatising the glant wild rice. It is making quite a good showing in two low country ponds.

our Ranger brought three or four stalks of siant w1ld rice to the councll meetling a few days ago and the members were astounded to see the quantity of seed which each ear contained.

Te have two very large salt-water lagoons in our district and are wondering if you could recommend anything for these. From your booklet it would apoear that "uskgrass or Sago pond Plant would be sultable.

Yours etc.

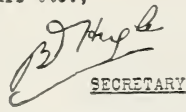

SIR FREDERICK W MOORE,

KEEPER

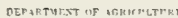

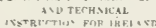

Deaz Kr. Terrel1,

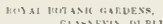
C1.1-VEVIS TI RLIX

IRELAND. Nov. 15th Nor, 15 tb

$I$ an now in a position to report on the results of the plantings.

I treated the $\pi 11 \mathrm{~d}$ Rice in various ways. I sowed it indoors, I Boxsd.1t outdoors in mud, and I soattered it in shallow water on the edge of the pond. This I did with the seed I received from you. I planted the Trapato Duck Potatoes along the margin of the pond. Ol all the methods of planting the W11d R1ce, scattering in shalion rater and leaving it to itself proved best. Fe bad an unusually dry warm sumer whicb sulted 1t well, quantities germinated and grew freely. Te bad it 3 to 4 feet high, a most grzeeful and beautiful sight when in florer. pond.

The Tapato Duck Potatoes grew vigorously and flowered in the same

I bave to thank you for giving me an opportunity of making these experiments.

I am,

Yours faithfully,

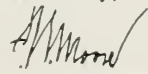

When you can buy results with Terrell's Sure-growing Giant Wild Rice seed ther - is no need to waste time and money with seed of uncertain growing qualities. 


\section{PLACES NOT SUITABLE}

UR experience has been that Wild Rice will not usually grow in waters having no outlet, waters salty to taste, or strongly alkaline. Places such as are found along parts of the Mississippi, Ohio and Illinois Rivers, where the water rises and stays ten feet or more above the normal water level for several weeks during the spring floods, are usually unsatisfac. tory places, as the Wild Rice is drowned out by the high water. If such conditions exist in your waters, you should plant other duck foods which we furnish, (described on the following pages) that are suitable for growing in such places.

\section{WHEN TO PLANT}

Wild Rice seed can be planted with excellent results during the fall, the natural time for planting it-Nature's sow. ing time.

\section{HOW MUCH TO PLANT}

2 bushels (60 lbs.) per acre of Terrell's sure-growing Giant Wild Rice seed should be planted to insure a good stand. If you plant a few bushels of Terrell's Giant Wild Rice seed now, this fall, it will produce a good Wild Rice bed to attract more ducks, muskrats and fish next fall. It reseeds itself year after year.

\section{PRICES}

$1000 \mathrm{lbs}$. or more $48 \mathrm{c}$ per $\mathrm{lb}$. 100 lbs. or more $50 \mathrm{c}$ per $\mathrm{lb}$.

1 bu. (30 lbs.) \$17.

Smaller lots 80c lb.; 92c lb. prepaid. 


\section{Wild Rice Marshes Make Money in Muskrats}

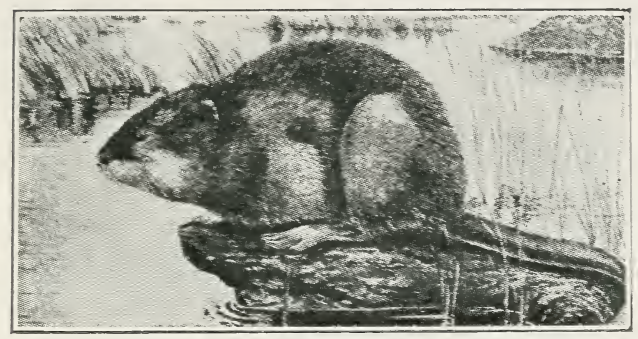

Wild Rice Marshes produce Hundreds of these Valuable Fur Bearers

W ILD Rice fields will support a lot of Muskrats as well as ducks. As Muskrat pelts average around $\$ 2$ each and live animals $\$ 7.50$ each, the owner of a Wild Rice marsh can make money from the sale of Muskrats for fur or breeding stock.

Wild Rice turns stretches of open water into grassy cover with open stretches of water here and there-just what ducks and Muskrats like for feeding, cover and breeding places. Muskrats use Wild Rice both as food and house-building material.

\section{WILD RICE MARSHES ATTRACT MUSKRATS}

Time and again where we have planted Wild Rice we have found that lots of Muskrats were attracted. Recently at Moon Lake Wild Life Refuge near Campbellsport, Wisconsin we found lots of Muskrats working in the Wild Rice beds.

Amid the abundant Wild Rice beds on our aquatic farm at Lake Butte des Morts, about 2000 Muskrats are taken each year. We always have lots of Wild Rice and lots of Muskrats. To feed a lot of Muskrats and ducks too, it is necessary to establish good sized beds. With Muskrat pelts averaging \$2 each and live animals around $\$ 7.50$ each, it is easy and profit. able to trap some Muskrats each year. Terrell's Giant Wild Rice will make your marsh support more Muskrats and there. fore make it more profitable. (Prices on Page 6.) 


\section{DO YOU LIKE GOOD THINGS TO EAT?}

\section{Wild Rice for Table Use}

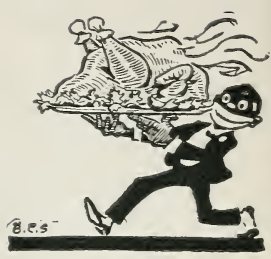

THE MOST UNUSUAL, HEALTHY AND COSTLY CEREAL IN AMERICA-BUT COSTS NO MORE THAN A DISH OF ICE CREAM

PHYSICIANS recommend Wild Rice as having more vitamines than any other cereal and declare it an excellent cereal to use as a breakfast food, a vegetable or dessert.

Terrell's Wild Rice For Table Use is hulled, recleaned and slightly parched, and has a tasty, nutty flavor unlike tame rice. A pound makes 15 servings costing about 10 cents per dish, about the same as a dish of ice cream.

\section{THE ORIGINAL AMERICAN HEALTH FOOD}

Wild Rice is the original American health food having been extensively used by the Menominee and Ojibwa Indians before white men came here. The Menominee Indians take their name from the Wild Rice plant. "Menomin" is their word for Wild Rice; "Menominee" means "Wild Rice people" or "Wild Rice eaters". A Menominee Indian will not sell his Wild Rice at any price unless he has first reserved a supply for his own use. They say that nothing sold in our modern grocery store tastes as good or is as healthy for them.

\section{TRY IT AT OUR RISK}

You are welcome to try a package of this unusual tasty, healthy cereal-enough for 10 dishes, at our risk. Cook similar to other cereals or try some of our favorite recipes, list of which is furnished free with each order. Just send a $\$ 1$ bill for a 10 ounce package of this unusual, tasty, healthful food, postage paid, and if not perfectly satisfied, say so, and your $\$ 1$ will be cheerfully refunded. You can buy in larger quantities at a saving.

\section{PRICES}

5 lbs. or more $\$ 1.45$ per lb. Smaller quantities $\$ 1.50$ per lb. postpaid. $10 \mathrm{oz}$. Trial Package, enough for 10 servings $\$ 1$. 


\section{Muskgrass - A Very Good Inexpensive Quick-Growing Duck and Fish Attraction.}

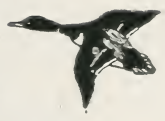

\section{MUSKGRASS ATTRACTS SWARMS OF DUCKS}

"The Muskgrass I planted has done very well. The ducks came in great quantity and seemed to like it very much as they stayed there constantly and were hard to drive away."

Dr. John M. Foster, Denver County, Colo.

$\mathbf{M}^{2}$

USKGRASS (Chara) is a good wild duck food plant which, if planted this fall, will produce an extensive growth next summer. Dr. McAtee of the U. S. Bureau of Biological Survey, who has examined the stomachs of hundreds of Wild ducks, to find out what foods they like best. finds that Muskgrass is eaten by Mallards, Black Ducks, Pintails, Widgeon, Gadwalls, Green-wing and Blue-wing Teal, Buffleheads, Golden Eyes, Ruddy Duck, Bluebills, and Redheads. It is a favorite food with Bluebills and Pintails, and where found, often makes up a large part of their food. They feed on the foliage as well as the many little tubers which it produces.

Muskgrass is one of the best cover and food producers for fish, especially young bass. (See page 22). It will make your waters produce more fish. If you raise decoys or tame ducks, Muskgrass will produce an abundance of cheap food for them.

\section{WHERE TO PLANT}

Muskgrass is easy to plant. Just scatter the "seed" (oogonia) covered plants. It grows rapidly and will grow over very poor sandy soil. It thrives in marl lakes and alkali or slightly salty waters, where many other plants will not grow, as well as in fresh waters. However, the water must contain some lime. If shells, which require lime, are common in your waters, this would indicate that there is lime in the waters, which makes the conditions satisfactory for growing Muskgrass. Muskgrass grows well in all parts of the U. S. and in the Canadian provinces. It grows entirely beneath the water, growing to a height of four inches to one foot above the bottom.

$$
\text { की } 9 \text { दु० }
$$




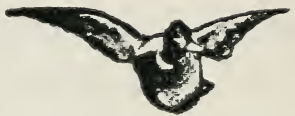

MUSKGRASS PLANTED ONLY IN FALL

Terrell's Muskgrass is harvested and shipped only during late summer and fall when the plants are covered with many "seed spores" or oogonia by means of which the plants reproduce. Only freshly gathered plants well covered with these "seed spores" are furnished. Without these "seed spores" the Muskgrass would not reproduce. Shipments are carefully packed in well-ventilated containers so that the Muskgrass goes through in first class condition. Plant 4 or 5 bushels per acre now and next season you will have lots of food for ducks and fish. Now ready. Be sure of getting your supply by sending in your order now.

\section{PRICES}

Plants covered with "seed" oogonia-\$6 per bushel. 1 BUSHEL FREE with every 5 bushel ordered, if no other special offers are applied.

\section{Terrell's Natural Duck Bait}

Contains Rice, Wild Duck Millet and other Duck Food seeds.

If you want a cheap bait to attract more ducks this fall and until your plantings get well started, scatter this bait in shallow water around the shores. Replace it as often as eaten. This Bait is superior to all others as it contains a large proportion of wild rice and wild duck millet seed, the natural foods of wild ducks. We can make a low price on this bait because any duck food seed showing inferior germination which we never sell for planting, goes into this bait. Considerable of the Wild Duck Millet will grow. Would you like to try a few hundred pound sacks?

PRICES -100 lbs. $\$ 10.00 ; 500$ lbs. or more, 9c a lb.; May be sent by freight.

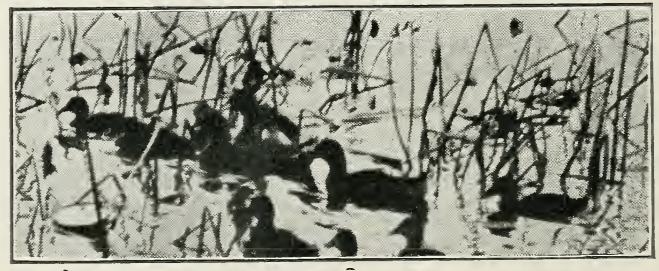

Ducks on a Lake where Terrell's Foods Were Planted. 


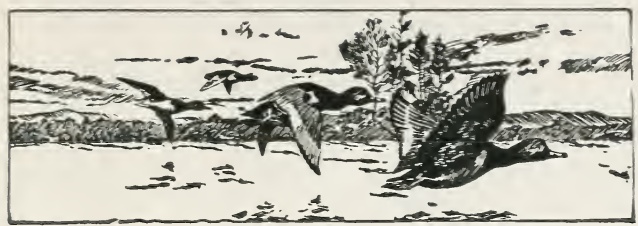

\section{Floating Brownleaf Pond Plant for Ducks and Fish}

\section{Thrives Almost Anywhere-No Transplanting Required}

FLOATING Brownleaf Pond Plant (Potamogeton natans) seeds resemble heads of wheat. A bed of these plants pro. duce as much duck food as so much wheat. These seeds are favorite food of such ducks as Mallards, Black Ducks, Teal, etc. Floating Brownleaf Pond Plant also makes an ideal shelter and food-producing plant for fish. One almost always finds $f \cdot h$ around beds of this plant.

The seeds and the brownish-colored oval leaves about two inches long, lie on the surface of the water. They do not grow above the surface.

\section{WHERE TO PLANT}

Floating Brownleaf Pond Plant is a very hardy plant grow: ing under a wide range of conditions. Grows from coast to coast in U. S. and Siuthern Canada. It will thrive in most any waters, fresh acid or alkaline waters, from $1 \frac{1 / 2}{2}$ to 5 feet in depth, on a mud, sandy, clay or marl bottom, but should be planted in places having a slight protection from heavy wash of waves.

\section{PLANT IN THE FALL}

This seed is obtained only for a short time during late summer and fall, and customers who desire to get some, should order AT ONCE. $40 \mathrm{lbs}$. of seed should be planted per acre. This is the natural planting time. Planted now the seed will lie dormant over winter and get an early start in the spring.

PRICE-Seed $\$ 1.50$ per pound.

\section{Duck Corn-Wampee (Peltandra virginica)}

A TTRACTS Wood Ducks. Produces large quantity of kernels similar to kernels of corn. Grows in acid swamps, marshy places, and shallow water. Does well in South. Will endure some shade, growing among trees where difficult to get other duck foods to grow.

Plant 10 lbs. seed per acre. Fall shipment. PRICE — $\$ 1$ per pound. You can plant a whole acre for $\$ 10$. 


\section{Sure Growing Wild Celery for Diving Ducks and Fish}

W ILD Celery is an ideal wild duck food that grows in deeper waters than Wild Rice. Also excellent cover and food producer for young fish.

Over forty years ago John K. Terrell, founder of Terrell's Aquatic Farm, brought our stock of Wild Celery from Chesa. peake Bay and planted it in our waters. This Wild Celery has been the cause of attracting thousands of Canvasbacks, Redheads and Bluebills to the neighborhood of Terrell Island on Lake Butte des Morts. These ducks feed on its tender white runners and buds even in 10 or 12 feet of water. Mallards, Pin. tails, Widgeons and other shallow water feeders steal it from Mr. Canvasback when he brings it to the surface or feed on it where it grows in shallow water.

\section{WILD CELERY ATTRACTS SWARMS OF DUCKS WHEREVER IT GROWS}

Wild Celery always attracts swarms of ducks wherever it is found as for example at Chesapeake Bay, Susquehanna Flats (Maryland), Currituck Sound, (North Carolina), marshes bordering on Lake Erie, St. Johns River (Florida), or St. Clair Flats (Ontario).

\section{EXCELLENT FOR FISH}

In addition to being a splendid wild duck food, Wild Celery furnishes excellent food and shelter for fish. These plants support countless numbers of minute insect and animal life which fish depend upon for food. Fish also eat portions of the plants themselves. A bed of Wild Celery will keep your waters pure and clear and well oxygen. ated, which is important for fish life. The plants provide shelter and hiding places for young fish, where they can escape from their enemies, assuring many more of them reaching maturity.

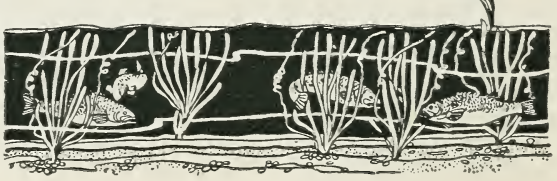

粘 12 देख 


\section{Hild Celery For Duchs And Fish}

\section{WHERE AND WHEN TO PLANT}

Almost any fresh water lake, pond or stream, containing a little lime as indicated by presence of shells, with a depth of 2 to 12 feet of water, and sand, mud or loam bottom, provides the right conditions for growing Wild Celery. This is a submerged plant growing entirely beneath the surface of the water. Deeper waters coming over it at flood times will not injure it. We have grown it successfully from Quebec to Florida and from Maine to Oregon. Wild Celery reseeds itself and spread in three ways-by runners, winter-buds (tubers), and seed which insures a continuous thrifty growth that spreads out and becomes more abundant from year to year.

\section{TERRELL'S WELL-RIPENED SEED PROPERLY HARVESTED AND SHIPPED, INSURES HIGH GERMINATION}

Terrell's Sure-Growing Wild Celery seed is fully ripened before harvested. It is shipped in the pods, each pod containing hundreds of the tiny well-ripened seeds. The seed is shipped only when freshly gathered, during the short harvesting sea. son in the fall. Any one who wishes to get Wild Celery seed for fall sowing, should order early to be sure to get their seed. Complete detailed planting instructions furnished with orders. 60 lbs. Wild Celery seed should be planted per acre.

\section{PRICES}

100 lbs. or more 90 cents per lb.; $10 \mathrm{lbs}$. or more $\$ 1$ per lb.; smaller lots $\$ 1.10$ per lb.; $\$ 1.22$ per lb. prepaid.

\section{WILD CELERY MAKES DUCK PARADISE}

"Wild Celery bought from you, Mr. Terrell, has thrived so well as also Wapato Duck Potato, that the lake looks to me like a duck paradise."

W. H. Thompson, Cuyahoga County, Ohio.

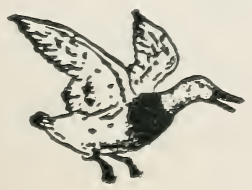

Canvasbacks Love Wild Celery 


\section{Naias (Bushy Pondweed) \\ For Mallards, Teal and Pintails \\ VALUABLE FISH FOOD AND COVER}

N AIAS (Naias flexilis) is an especially important food for Mallards, Pintails, Green-winged and Blue-winged Teal. These birds congregate over the Naias beds to feed on the crisp, tender plants, and the tiny brown seeds that cover these plants profusely in late summer and fall. Black Ducks, Gadwalls and Widgeon also feed eagerly on this plant whenever they can get it. Naias is also valuable for fish food and cover (see page 22).

\section{WHERE TO PLANT}

Naias should be planted in quiet or slow-moving, fresh or slightly brackish water from 1 to 6 feet in depth, on almost any kind of bottom soil, except rocky. Does well over most of the U. S. and Canada.

\section{FRESHLY GATHERED, WELL-RIPENED SEED FURNISHED IN FALL}

These plants must be freshly gathered for each shipment, and are gathered only when the plants are covered with the countless numbers of well-ripened small brown seeds from which it reproduces. Ready for immediate shipment. Not usually available after October 15 th.

\section{PRICES}

Plants with ripe seed- $\$ 10$ per bushel. Plant 5 bushels per acre.

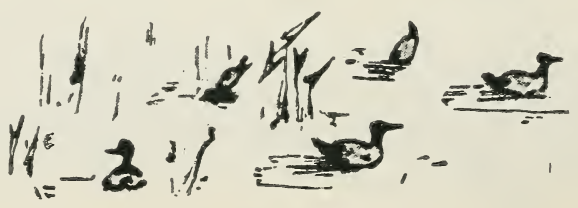




\section{Water Cress}

\section{FOOD FOR MAN, DUCKS AND TROUT}

W ATER Cress (Sisymbrium Nasturtium-aquaticum) is a fast growing wild duck food, growing in shallow streams, springs or fountains, in water from 1 to 8 inches deep. Where waters do not freeze over, the Water Cress will remain green all winter. We have heard of Black Ducks staying at a property all winter long, living chiefly on the Water Cress growing in some open streams there.

Water Cress is also considered valuable as a food for ducks raised in captivity.

\section{WATER CRESS IMPROVES TROUT FISHING}

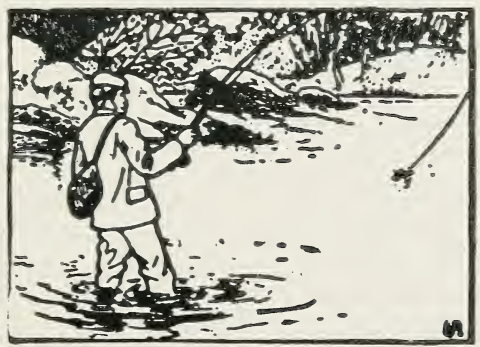

Water Cress is very desirable for trout streams as it thrives in cold water and provides excellent food in the form of insect life. The plants also furnish good cover for the speckled beauties. Plant beds of Water Cress and develop some good trout holes where you can catch bigger trout. Plenty of food will insure their growing big. Very desirable for planting around hatcheries.

\section{HAVE YOU EATEN WATER CRESS?}

Water Cress is delicious in salads and sandwiches, and with fish and meats. Served in the better hotels and restaurants. Something unusual for your table.

\section{EASILY GROWN}

Water Cress is easily grown by planting the plant in fall. In planting simply stick the Water Cress plant roots into the soil in shallow water and mud around springs, flowing wells and shallow brooks. It will grow throughout the U. S. and southern Canada. Plant 1000 plants per acre this fall and you will soon have Water Cress beds established. Now is the time to get the plants.

PRICES-Plants for fall planting: $1000-\$ 30 ; 500-\$ 15 ; 300$ or more $\$ 3.50$ per $100 ; 100-\$ 5$. 


\section{Wild Grape}

\section{FOOD FOR WILD DUCKS, QUAIL, RUFFED GROUSE, SONG BIRDS AND MEN-ORNAMENTAL TOO}

DID you know that when growing on banks of lakes, ponds and streams, the Wild Grape is eagerly eaten by Mallards, Black Ducks, Green-winged Teal, Pintails and Wood Ducks? The vines also offer cover for these ducks. 339 Mallards, 141 Wood Ducks, 22 Green-winged Teal and 11 Pintail stomachs examined by the U. S. Biological Survey contained Wild Grapes. These Wild Grapes are widely used and sold for jams, jellies and fruit juice.

Wild Grapes are fine food and cover-producers for Ruffed Grouse, Quail, Pheasants and song birds. For upland game birds, Wild Frost Grapes and Wild Summer Grapes can be planted along fences, over stumps, trees and around buildings, as well as along the banks of lakes and streams. Extensively used for shading and screening blinds, buildings and porches. There is nothing except the evergreens that will make such good cover for upland game birds, as these Wild Grape vines. Wild Grapes have the advantage of furnishing food as well as shelter.

\section{PLANT THIS FALL}

Dormant vines should be planted during fall and until freeze-up.

\section{PRICES}

Wild Summer Grapes. (Vitis aestivalis) grows from New Hampshire and Southern Ontario to Gulf of Mexico, west to Kansas and Texas, on dry uplands, and thickets. Fruit ripe September and October. Pleasant tasting. 2 to 3 yr. vines -100 or more $35 \mathrm{c}$ each; 10 for $\$ 4.50$.

Wild Frost Grape (Vitis cordifolia) grows from Southern New York and New Jersey South to Florida and Texas, West to Wisconsin, Nebraska and Southwest in moist thickets and along shores of lakes and streams. 2 yr. vines -1000 or more $10 \mathrm{c}$ each: $100-\$ 15 ; 10$ for $\$ 3.50$.

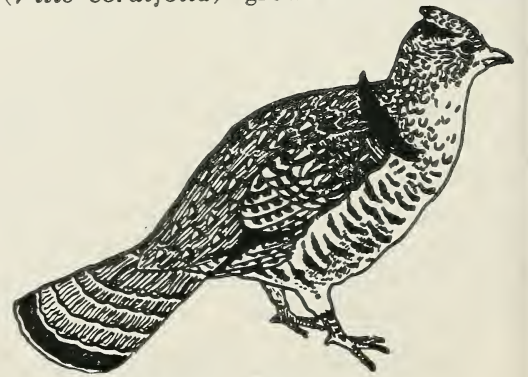

Ruffed Grouse and Quail Love Wild Grapes 


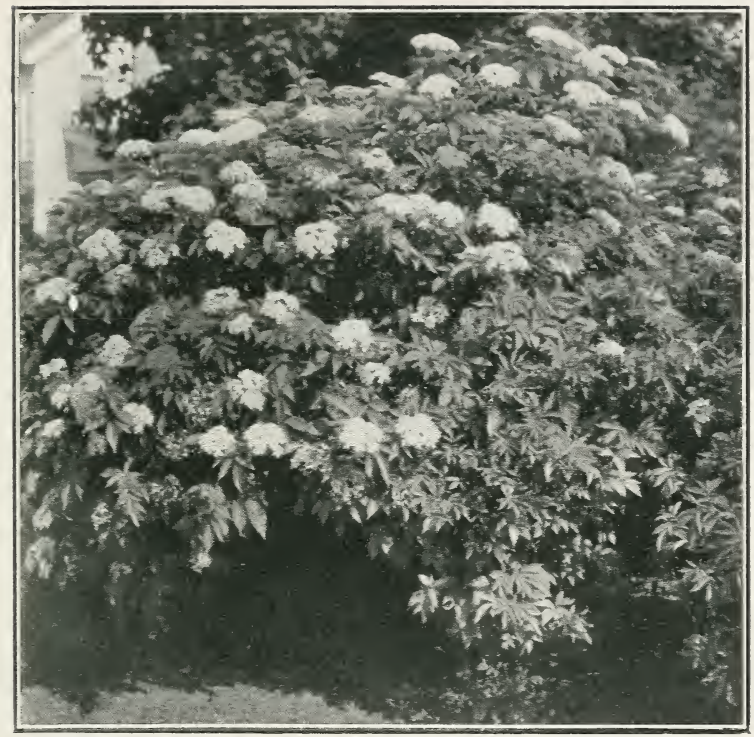

\section{Elderberry (Sambucus)}

ATTRACTS QUAIL, DUCKS, AND OVER 90 OTHER BIRDS VERY ORNAMENTAL

DUCKS, Quail, Ruffed Grouse, Mockingbirds, Robins, Bluebirds and over 90 other birds eat Elderberries. The U. S. Biological Survey in making examinations found Elderberries in the stomachs of 32 Pintails. Also eaten by other ducks. Good for ornamental planting around homes and summer cottages. Grows in moist as well as dry ground. Thrives over entire U. S. and Canada.

RED-BERRIED ELDER (Sambucus racemosa)-Has large clusters of attractive white flowers in early spring, (see illustration above) and bright orange-red berries in midsummer. Should not be eaten by mankind.

SWEET ELDER or ELDERBERRY (Sambucus canadensis) Has large clusters of very sweet-scented white blossoms in midsummer and deep purple or black berries in fall. This variety is edible and used for pies, jams and fruit juice. Best variety for damp places. PRICES-EITHER KIND-(State Kind Desired)

Many people plant both varieties to bloom and furnish food at different seasons. Large 4 to $5 \mathrm{ft}$. shrubs properly matured for fall planting - produce flowers and berries first year: $3-\$ 3 ; 10-$ $\$ 8.50 ; 100-\$ 75$.

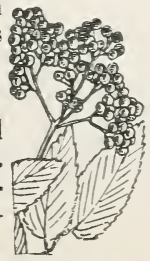




\section{Sumac Attracts}

\section{Quail, Ruffed Grouse Prairie Chickens, Ducks and Song Birds}

\section{IMPORTANT WINTER FOOD}

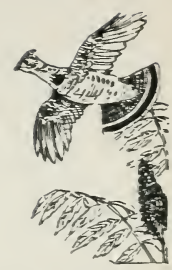

M ALLARDS, Black Ducks, Gadwalls and Wood Ducks eat

Sumac as shown by stomach examinations made by the U. S. Biological Survey. Important winter food for Quail, Ruffed Grouse, Prairie Chicken and song birds. The seed heads extend well above the snow where they feed the birds in time of need. 90 kinds of birds feed on Sumacs. Each shrub pro. duces many seed heads each containing about one-half cup of seed.

\section{WHERE IT GROWS}

Sumac grows throughout the U. S. and southern Canada. Thrives on dry soil, near lakes and along streams, as well as on uplands. The feathery foliage turning red in fall and red seed heads make it very attractive for ornamental planting. It grows very fast-Sumac planted at our home has grown fully 5 feet in one season. Sumac does not usually produce seed until it is several years old, so it is better to plant larger and older shrubs such as we offer this fall. They will soon produce seed. These shrubs spread by means of seeds and run. ners. Fall plantings produce the best of results.

STAGHORN SUMAC (Rhus typhina), New bark velvetlike. Grows up to 40 feet high.

SMOOTH SUMAC (Rhus glabra). Smooth bark. Grows up to 20 feet high.

Neither variety is poisonous. Both equally valuable for bird food and ornament.

\section{PRICES-EITHER VARIETY}

6 to $7 \mathrm{ft}$. large fine specimens, will soon produce seed. 3 for $\$ 3 ; 10$ for $\$ 8.50 ; 100$ for $\$ 75$.

\section{SUMAC IMPORTANT FOR QUAIL}

(From U. S. Biological Survey Bulletin No. 21)

"Sumac bushes... along hedgerows and the edge of woodland ... furnish food that is always above the snow and lasts well into spring ... Bobwhites collected in December had made nine-tenths of their food of Sumac, having eaten from 50 to 300 berries each." 


\section{Large Bur Reed for Black Ducks}

THIS is an excellent wild duck food, produc.

ing a large quantity of kernels eagerly sought for by the ducks. It is also an odd ornamental plant.

FOR SHALLOW WATER, SHORES OR MARSH

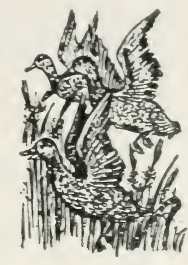

BUR REED (Sparganium eurycarpum) grows to a height of 4 feet, making excellent cover. Grows in marshy, muddy spots or in water up to a foot in depth.

\section{WHEN TO PLANT}

Seed furnished for fall planting if desired, but we recom. mend the planting of Bur Reed roots in the spring, as the better way of getting Bur Reed established.

\section{PRICES}

Plant 10 lbs. seed or 1,000 roots per acre. Seed for fall planting $\$ 1.50$ per $\mathrm{lb}$. Roots for spring planting, 1000 $500-\$ 37.50 ; 100-\$ 10$.

\section{FREE PLANTING MATERIAL}

If Bur Reed roots for spring delivery are ordered before January 1st, $20 \%$ more roots than order calls for, will be sent FREE OF CHARGE.

\section{Sago Pond Plant (Potamogeton pectinatus)} FOR DUCKS AND FISH

A WELL known food and attraction for wild ducks and a A splendid food and cover producer for fish. Suitable for alkali, marl or slightly salty waters as well as fresh water containing lime. Seed is sometimes sold for fall planting but we have found that quicker results are produced by planting the tubers in spring. Orders for tubers can be entered now.

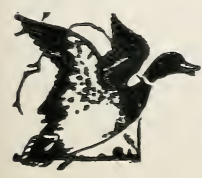

PRICES FOR SPRING DELIVERY

1000 tubers- $\$ 15 ; \quad 500-\$ 22.50 ; \quad 100-\$ 6.50$ Plant 1000 tubers per acre. 20\% more tubers FREE if ordered before January 1st. 


\section{How to Get MORE AND BIGGER FISH}

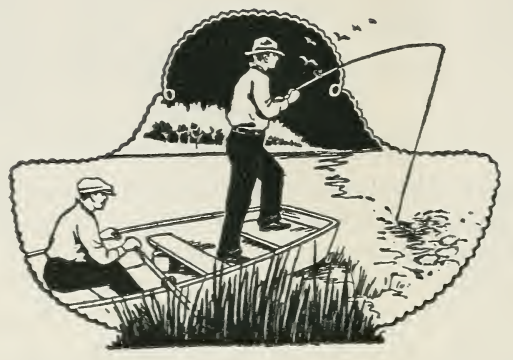

I F YOU want to get big fish instead of little ones, make sure the fish get plenty to eat. Fish, as well as children, need enough suitable food if they are to grow big, healthy, and full of pep. Well fed fish grow about three times as fast as half starved fish grow, according to tests made at State and Federal fish hatcheries.

You no doubt have fished in lakes where the fish never get to be very large. This as well as diseases of the fish is often due to lack of food. More food means that more fish can be produced in your waters, just as more cattle can be raised on a good pasture with plenty of food, than on a poor pasture.

\section{FISH NEED FOOD}

If you want more, healthy and bigger fish, provide plenty of food for them by stocking your waters with frogs and crawfish, two of their favorite foods, and plant Wild Celery, Muskgrass, Wild Rice and Naias. These plants are splendid oxygenators, and water purifiers. Fish feed on parts of the plants themselves, and on the forms of small insects, shells, and animal life that these plants support. The plants also make shelter where the young fish may escape from their enemies. More food and shelter will produce many more and bigger fish for you. 


\section{Four Important Food-Producing and Shelter Plants for Fish}

\section{Wild Celery, Wild Rice, Muskgrass, and Naias for Fall Planting}

THESE plants will help your waters to produce more and bigger fish. You will always find more fish and better fishing around beds of these plants. Mr. H. O. Preston says in an article entitled "The Scrappy Black Bass" in a recent issue of "Associated Sportsmen", "The edge of the weed beds (water plants) furnishes excellent cover, and in spots of this kind the lure should be cast."

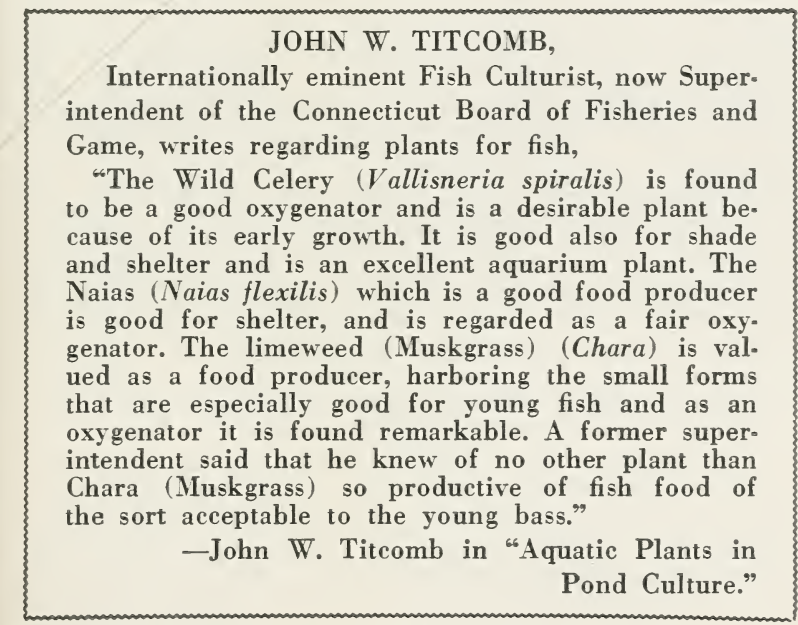

WILD CELERY grows submerged. Good fish food and cover. Purifies water. (Detailed description on pages 12 and 13.

\section{PRICES}

Freshly gathered, fully-ripened Wild Celery seed in pod now ready for shipment. $100 \mathrm{lbs}$. or more $90 \mathrm{c} \mathrm{lb}$; $10 \mathrm{lbs}$. or more $\$ 1 \mathrm{lb}$; s smaller lots $\$ 1.10 \mathrm{lb}$.

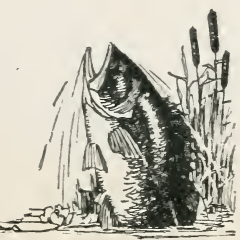




\section{Fish Food and Shelter}

MUSKGRASS (Chara) Grows submerged about 1 foot high on the bottom. Provides very good food and cover for fish, highly desirable for bass. Quick-growing, inexpensive. (Full description given on pages 9-10). Bluegills examined by $\mathrm{Dr}$. A. S. Pearse of the U. S. Bureau of Fisheries had eaten large quantities of this plant, one having made $99 \%$ of its last meal of Muskgrass (Chara). Dr. Pearse also found it to make up as much as $20 \%$ of the food of pickeral examined.

PRICES-Plants with well-ripened "oogonia" (seed spores), ready for immediate shipment. Plant 5 bushels per acre. $\$ 6$ per bu.; 1 bu. FREE with each 5 bu. ordered.

NAIAS (Naias flexilis) Good fish food producer. Ideal cover for young fish. Purifies water. Grows submerged on bot. tom about 8 inches high. (Full description on pages 9 and 10).

PRICES: Plants with quantities of small ripe seeds, now ready for planting. Plant 5 bushels per acre. $\$ 10$ per bushel.

GIANT WILD RICE At the Sylvania Clus in Upper Michigan, I noticed black bass had built their nests among Wild Rice that had been planted for them. Sheridon Jones prominent angling authority writes in "Fishing Facts" that Pickeral and Muskellonge "will be found in coves abounding in Wild Rice." For information on growing Wild Rice, see pages 3 to 6 .

PRICES-1000 lbs-48c lb.; 100 lbs. - 50c lb.; 1 bu. (30 lbs.) — $\$ 17$; smaller lots $80 \mathrm{c} \mathrm{lb}$; prepaid $92 \mathrm{c} \mathrm{lb}$.

\section{PLANT MORE FOOD AND YOUR LAKE WILL SUPPORT MORE FISH}

E. C. Fearnow, Superintendent of Fish Distribution (1924) U. S. Bureau of Fisheries, says-

"A given area of ground will furnish forage for just so many cattle, and when more are added it means less food per capita. The same rule applies to fish, and no more should be placed in a body of water than the natural food supply will maintain."

-From "Stocking Interior Waters of the U. S."

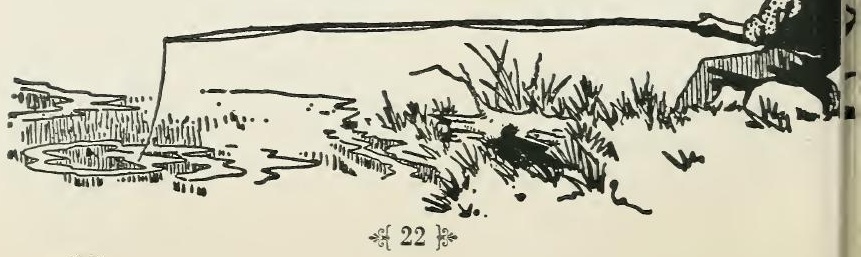




\title{
LIVE FROGS AND CRAWFISH
}

\author{
For Bait and Stocking Purposes \\ FOR FISH FOOD
}

FROGS. Leopard Frogs (Rana pipiens). Recommended for bass bait by leading fishing clubs, and fishing authorities. Frogs will help keep down mosquitoes. A few years ago a large real estate development company in

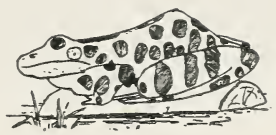

Florida had a large consignment of frogs sent down to them for liberating in a new subdivision they were developing to help rid the locality of mosquitoes.

Regular prompt delivery from July to November. Shipment as often as desired. Medium size-about $2 \frac{1}{2}$ to 3 inches long stretched out.

\section{PRICES}

Frogs $1000-\$ 45 ; 500-\$ 22.50 ; 100-\$ 5$. F. O. B. Oshkosh, Wisconsin.

CRAYFISH, CRAWFISH OR FRESH WATER "CRABS"

For Fish Food and Bait

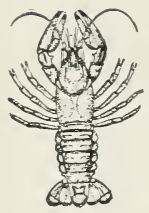

These make excellent food and bait for large-mouth, small-mouth and rock bass, sunfish, bullheads, catfish, perch, brook trout and bluegills. Crawfish should be planted only in lakes containing lime which is usually indicated by the presence of shells. Prompt delivery during late summer and fall for bait or stocking waters. Weekly shipments if desired.

\section{PRICES}

$5000-\$ 30$ per $1000 ; 1000-\$ 35 ; 500-\$ 17: 50 ; 100-\$ 5$.

WE GUARANTEE safe delivery of frogs and crawfish when shipped within 600 miles of Oshkosh, Wisconsin. We frequent. ly ship successfully over 1,000 miles. Should any die in transit have your express agent report number dead on arrival, to us for adjustment.

One of our customers on Long Island, to whom we sent a shipment of frogs in July, wrote us as follows:

"You will doubtless be interested to know how the frogs made out on the long trip from your place to mine on Long Island. You evidently expected a death rate, for I think there must have been nearly a dozen extra frogs in the box. There was only one dead frog in the shipment and the others were in fine shape."

-Leroy Latham. 


\section{Planting Helps Gladly Given}

Helpful detailed planting instructions for each item are sent with every order. We are always glad however, to help you in suggesting what is best to plant under conditions of certain waters, if you are in doubt about it. We have had 33 years practical experience in planting these foods for wild ducks, birds, muskrats, fish and other game in various parts of the country. We have a complete line of food and cover plants for all kinds of wild life including water plants, and berry bearing trees, shrubs and vines. Something for practically every condition. Often we are able to make suggestions which help materially in getting the best results.

\section{PROPERTIES PERSONALLY EXAMINED}

While we are always glad to give all help we can by cor. respondence free of charge, clubs and owners of fairly large properties will often find it to their advantage to have us personally visit and examine their properties and determine just what is best suited to their particular purpose and just where to make plantings, thus insuring the best possible results, and in many cases saving time, planting material, and money.

\section{PLANTINGS CARRIED OUT IF DESIRED}

Services of a capable and experienced man may also be secured to make plantings. Many people use this service who want the advantage of better feeding grounds for fish and game, but who have not the time to do the work themselves, $0:$ have no person to whom they can entrust the work. This service is a good investment, for such a man, by his experience and judicious planting, can often produce better results with a much smaller amount of planting material than an inexperienced person. Those desiring to take advantage of this are in. vited to write to us for estimates of cost of such service, describing and giving size and location of waters.

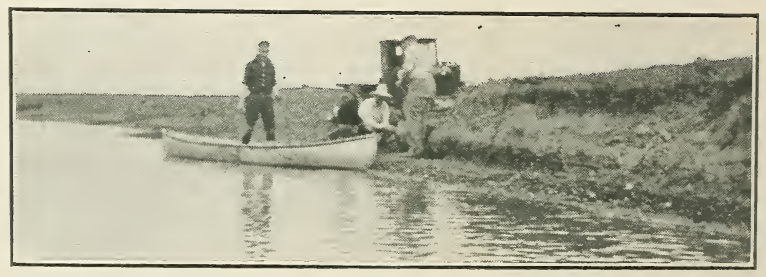

Terrell's Crew Planting Lake Adam, Mont. 


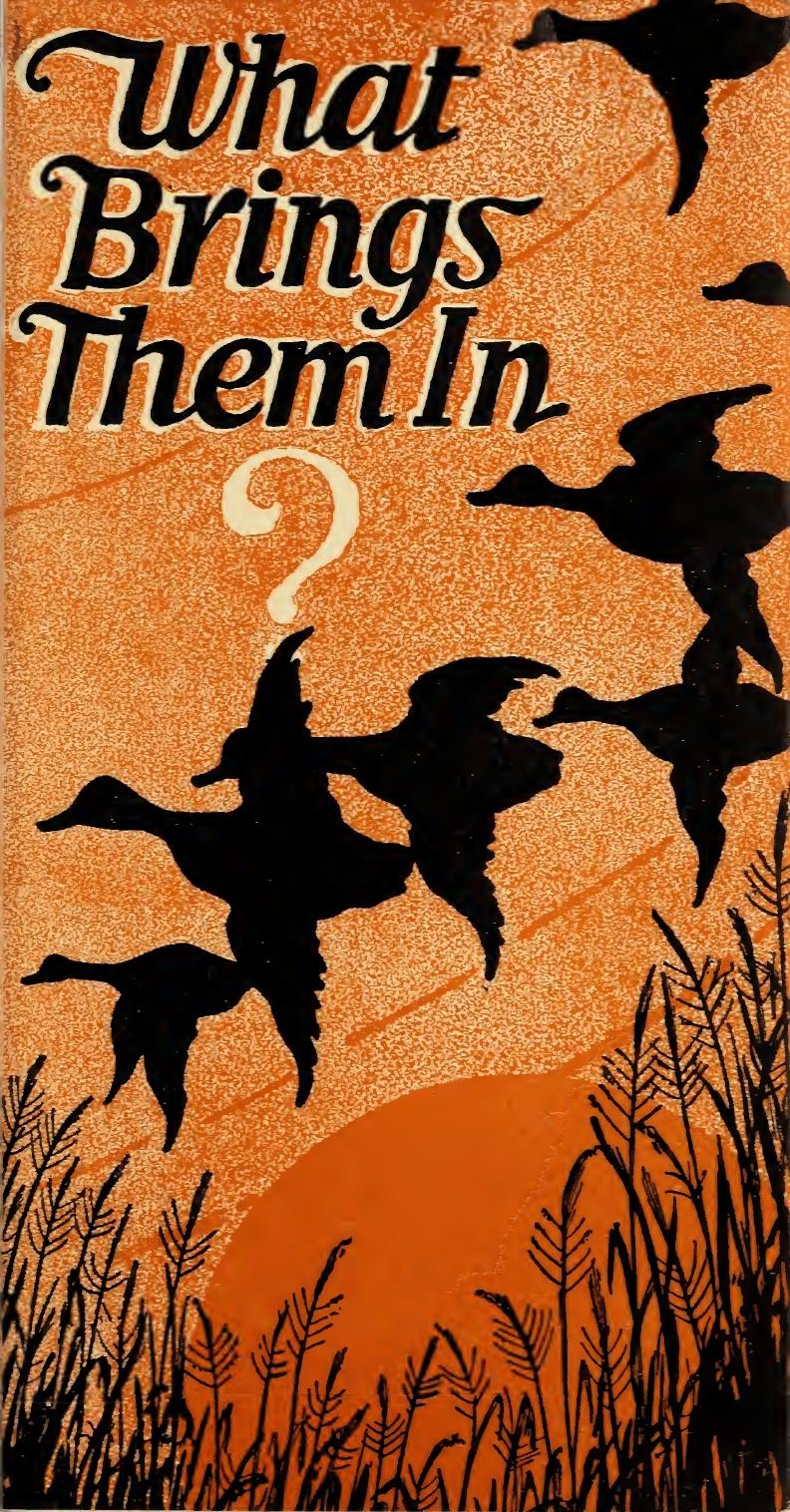




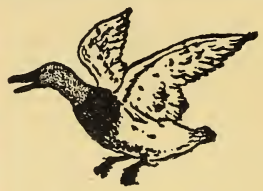

\section{Wild Celery Brings} Canvasbacks! Bluebills! Redheads! Fish!

These ducks feed on Wild Celery (Vallisneria spiralis) in preference to other foods. Other ducks which feed on Wild Celery include the wood duck, widgeon, pintail, ruddy, bufflehead, whistler, teal, scoters, mallard and black duck. Geese, swans and coots also eat it.

Prominent fish culturists recognize Wild Celery as one of the best plants for "fish pastures." It is an ideal fish food and cover.

Wild Celery thrives in fresh or slightly brackish waters in sheltered bays, 2 to 8 feet deep. Thrives in practically all parts of United States and Canada. Easily grown from Terrell's sure-growing, well-ripened Wild Celery seed.

NOW IS THE TIME to send your order. After this short harvesting season is over, we will be unable to get more seed until another year. 60 lbs. will plant an acre. Plant now or any time before the freeze-up. See order blank for prices.

\section{Floating Brownleaf Pond Plant Attracts Wild Ducks and Fish!}

Mallards and Black Ducks, in fact all kinds of marsh ducks, are very fond of feeding upon the seeds of the Floating Brownleaf Pond Plant (Potamogeton natans). Good fishing is usually found around beds of this plant.

Floating Brownleaf Pond Plant is a very hardy plant growing in northern United States and Canada. It will thrive in most any fresh waters from $11 / 2$ to 5 feet in depth, on a mud. sandy, clay or marl bottom. It grows in ponds or sluggish streams, also in open waters but produces best results in sheltered bays or coves. Seeds should be planted in late summer or fall. $40 \mathrm{lbs}$. plants 1 acre. See order blank for prices.

\section{Water Cress Attracts} Ducks and Fish

If you have a spring or fountain where water is only a few inches deep, and remains unfrozen during winter, set out a few Water Cress (Sisymbrium) plants. They spread rapidly and besides feeding wild ducks, trout and other fish, it makes a delightful salad for your table. See prices on order blank.
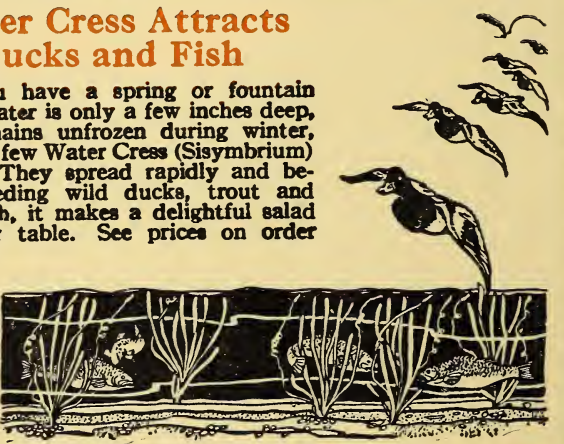
ORDER BLANK AND PRIGE LIST

Effective October 1, 1930

TERRELL'S

AQUATIC FARMS \& NURSERIES

OSHKOSH, WISCONSIN, U.S.A.

Ship to

(Full Name)

Address

Ibs. Glant Wild Rice, selected sure-growing seed, 500 lbs. or more $48 \mathrm{c} \mathrm{lb}$.; 100 lbs. or more $50 \mathrm{c} \mathrm{lb.;}$ $30 \mathrm{lbs}$. or $1 \mathrm{bu}$. $\$ 17$; smaller lots $80 \mathrm{c}$ lb. Post-

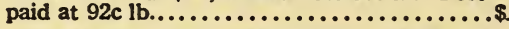

Ibo. Wild Celery Seed, well-ripened-100 lbs. or more $80 \mathrm{c}$ lb.; $10 \mathrm{lbs}$. or more $82 \mathrm{clb}$.; F. O. B. Oshkosh. Smaller lots $\$ 1 \mathrm{lb}$. postpaid........\$

bu. Muskgrass, with well-ripened seed spores, 5 bu. $\$ 22.50$ (plants 1 acre); $\$ 5$ per bu......... \$

lbs. Floating Brownleaf Pond Plant Seed, $\$ 1.50$ per $\mathrm{lb}$; $\$ 1.62$ per lb. postpaid..............\$

bu. Nalas Plante covered with ripe seed, $\$ 10$ per bu............................... Water Cress vigorous plants, $\$ 30$ per 1,000 ; 300 or more $\$ 3.50$ per $100 ; 100$ for $\$ 5 . \ldots \ldots . \$$

lbs. Natural Duck Bait, 100 lbs. for $\$ 12 ; 500$ lbs. or more $10 \mathrm{c}$ per lb.; small lots $15 \mathrm{c} 1 \mathrm{~b} . . . \ldots \ldots . \$$

lbs. Choice Wild Rice for Table Use, 5 lbs. or more $80 \mathrm{c}$ per $\mathrm{lb}$., or $90 \mathrm{c} \mathrm{lb}$. postpaid; smaller lots $\$ 1$ per lb. postpaid...................\$

lbe. Same as above, but more broken at $1 / 2$ price. .\$

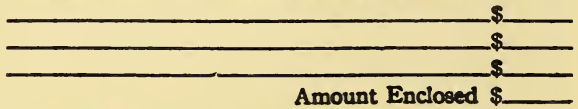

$2 \%$ discount for cash with order.

All prices F. O. B. Oshkosh unless otherwise stated.

Ordered by

Addrese

\section{PERSONAL INVESTIGATION AND PLANTING}

\section{SERVICE}

While we are always glad to give all help we can by correspondence free of charge, clubs and owners of fairly large properties will often find it to their advantage to have us personally examine their properties and recommend what is best suited to the conditions, and just where to make plantings, thus insuring the best possible results.

Services of a capable and experienced man may also be secured to make plantings. Write us for estimate of cost of such service. WATER AND WATERFRONT PLANTING 


\section{Out Song Birds ate Worth Millions}

THEY SAVE THE TREES, FRUIT AND FLOWERS

The Following Wild Song Birds will use Feeders:

Downy Woodpecker Cedar Bird

Titmice

Red Birds

Chickadees

Nuthatches

Winter Wrens

Junco

Robins

Goldfinch
Song Sparrows

Swamp Sparrows

Flicker

Redpoll

Blue Jay

Mocking Bird

Brown Creeper

Hairy Woodpecker

Our Feeders are endorsed by the birds themselves.

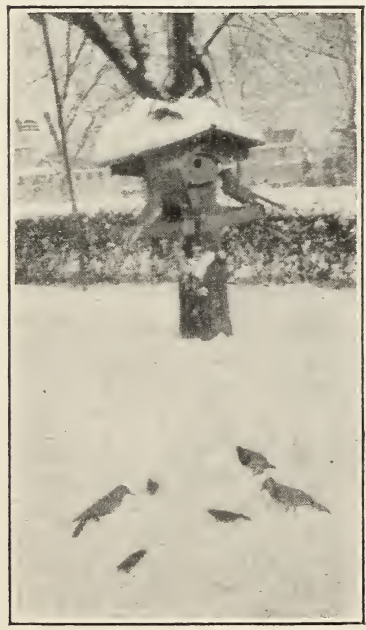

Feeders are most acceptable gifts.

A never ending joy to the invalid or Child.

Feeders are Used Every Month of the Year 


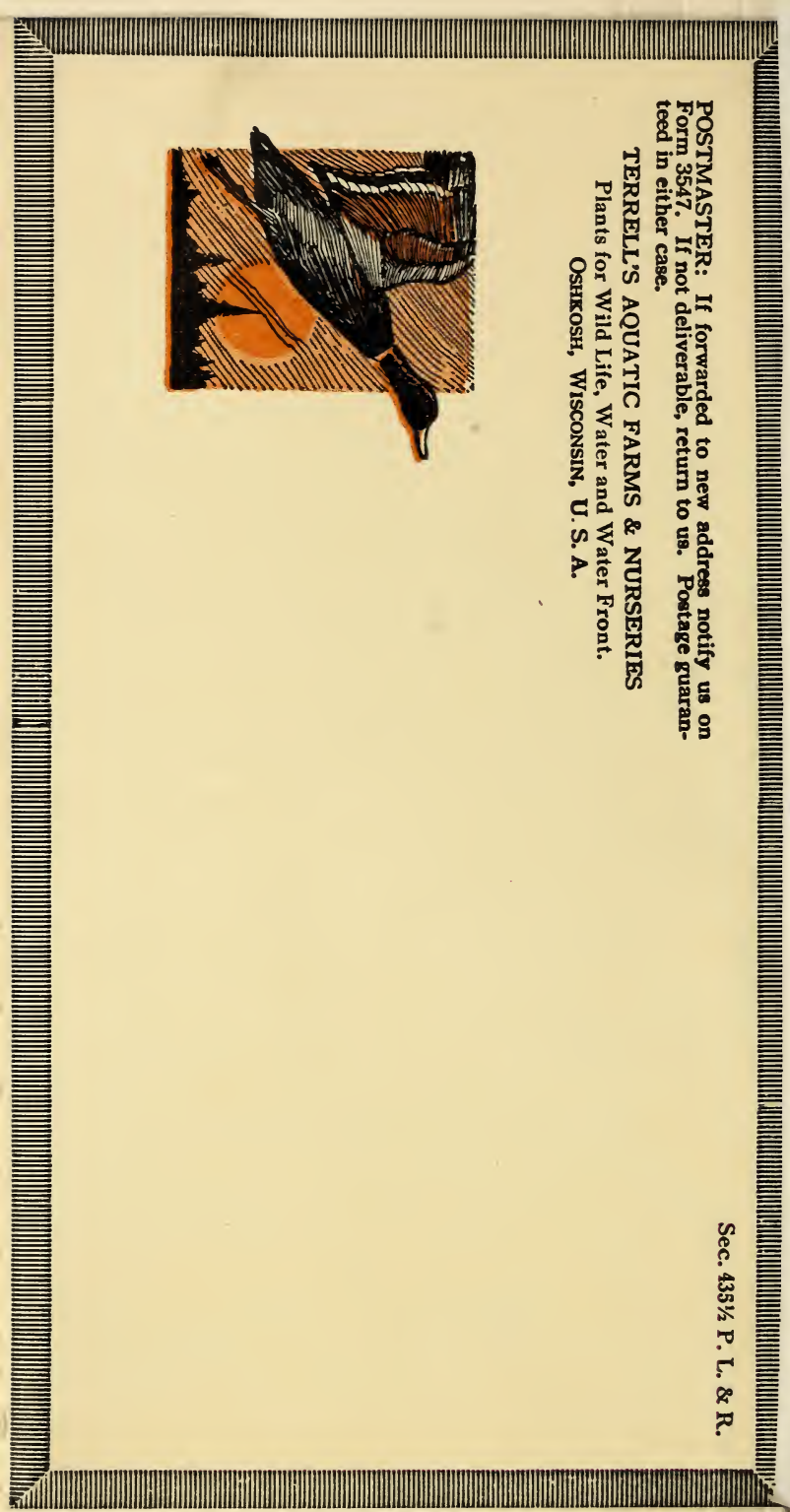




\section{SAVE THE SONG BIRDS}

WITH OUR 2-IN-1 FEEDER

Provide your feathered friends with food during the time of stress and storm. An extreme cold spell, or a continuation of snow on the ground, means the death of thousands of song birds. Why not do your bit to help them?

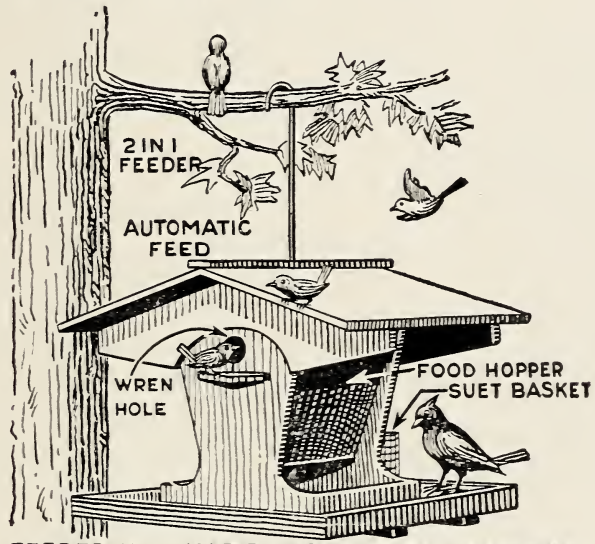

FEEDER IN WINTER. WREN HOUSE IN SUMMER

To hook over Raise roof to fill.

limb of tree. Holds two quarts.

Will last for years. Made of wood.

Stained brown. Size $12 \times 10 \times 11$ "

Will attract birds from far and near in the Winter and

Wrens love it for a house in the

summer.

Price Only $\$ 2.50$ Post Paid TERRELL'S

Aquatic Farms \& Nurseries

Oshkosh, Wis. 


\section{What is Happening to Our Supply of Migratory Waterfow1?}

The number of migratory waterfow is rapidly decreasing. Many blame the fellow pictured at the right. He may be partly to blame but a good share of the blame lies in a cifferent direction. Dr. Nelson, Chief of Bureau of Biological Survey, Washington, D. C., says wild ducks are starving to death, and goes on to say:

"Drainage has gone on to such an extent in the United States that the number of migratory wild fowl has reached the practical limit of available food supply, and every water area that is now drained takes away that much of the feeding grounds of these birds. It is perfectly obvious if that condition continues that we are going to continue to whittle down the supply of wildfowl, because they must have a place in which to live, no matter whether they breed there, or whether they merely use it during migration and in the winter. The supply of birds in many places is already beginning to be greater than the food supply, and they are actually starving on certain feeding grounds. This will increase, and unless there is some effort made to save the water areas the inevitable result is going to be the wiping out of our wildfowl. If the birds disappear for that cause, that ends it. You cannot bring them back."

Will Dilg, President of the Izaak IValton League of America, says:

"We have drained and drained, and today. we are confronted with the awful fact that we have drained an area equalling the five Great Lakes and eleven million acres besides. And the trage$d y$ is that in our ignorance less than one-third of this wholesale drainage has resulted in even indifferent farmlands. We have made deserts of once lovely places in which migratory fowl and all sorts of wild life found food and resting places. Today wildfowl frequently starve during the southern and northern flights. God forgive us for such awful stupidity!"

We Can Do One Thing to Make Amends-

Restore and Establish Natural Feeeding Grounds for Our Wild Waterfow1: 


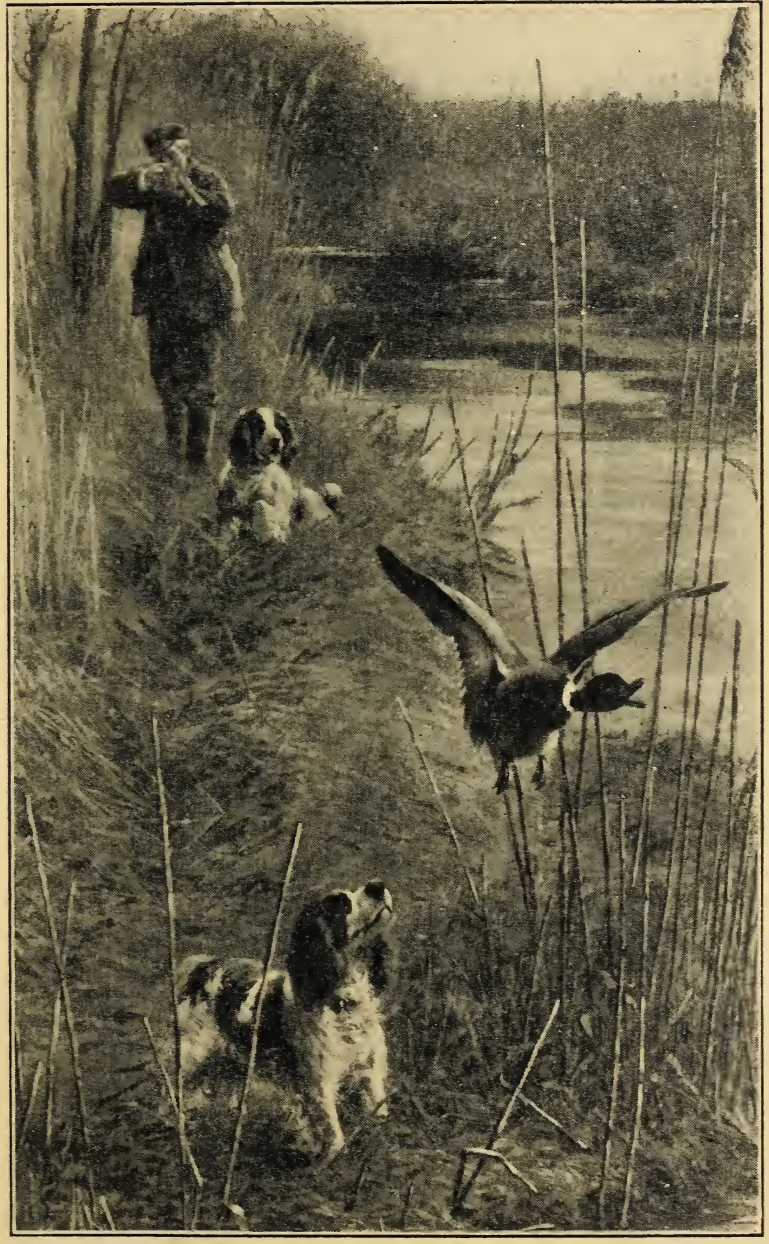


PRINTED IN U. S. A. 

as "Wild Rice,"and is given about the same rank as a duck food, as the Wild Rice in the North. Mallards, Black Ducks and other Marsh Ducks love it.

Wild Duck Millet grows on damp lowlands, mud flats, or on the rich damp soil along the shore, just above the water's edge. The seed may be sown broadcast.

Plant Wild Duck Millet seed now using 40 fbs. per acre. It will mature furnishing abundant food for the wild ducks next fall. The seed is inexpensive, selling at $\$ 20$. per 100 lbs; $\$ 3.00$ for 10 . (No quantity less than 10 tbs. sold.) Prices F. O. B. Oshkosh.

\section{WAPATO DUCK pOtato}

\section{EXCELLENT ATTRACTION FOR MALLARDS AND OTHER MARSH DUCKS!}

Mr. L. E. Selby of Pekin, Illinois, planted a large bed of Wapato one spring and a year or so later, wrote:

"The ducks can hardly be driven out of them after they once find the bed. The other day I was out at the club and the ducks were then setting on the ice waiting for the ice to melt so they could get at the Duck Potatoes that were left over last fall."

I told him that was fetching it pretty strong, and he then said he would take me up and show them to me. However, we have proven it to our own satisfaction.

This is your last chance to get Wapato Duck Potato tubers for spring planting. Plant now to provide food for the wild ducks next fall. 1,200 tubers plant an acre.
3,000 tubers@ $\$ 33.00$ per 1,1000
1,000 tubers@ $\$ 35.00$
500 tubers@\$20.00
100 tubers@\$5.00

\section{CANVASBACKS! REDHEADS: Wild Celery}

All parts of the Wild Celery are eaten by the ducks, but Canvasbacks and Redheads prefer the tender roots and tubers produced by this plant.

Where Wild Celery does not grow naturally, it is a very easy matter to establish some fine beds by planting a thousand or two of these winter-buds this spring. 1,000 winter. buds will plant an acre. Plantings should be made soon as possible.

5,000 or more winter-buds @ $\$ 33.00$ per 1,000

500 winter-buds@ $\$ 22.00$

1,000 winter-buds@ $\$ 38.00$

100 winter.buds@\$5.00

\section{Sago Pond Plant}

When everything else fails, you can usually be sure of Sago Pond Plant proving successful. It grows under almost any condition, fresh or brackish, landlocked or running waters from one and one-half to six feet deep.

All kinds of ducks love it and feed on it from early until late fall, and in the North, only the freeze-up will drive them out.

We are shipping out Sago Pond Plant tubers for planting now. Five hundred or a thousand of these planted now, will insure you of more ducks in the future. This is the last call for spring planting.

1,000 tubers@ $\$ 60.00$

500 tubers@ $\$ 35.00$

100 tubers@\$7.50

Complete instructions for planting furnished with all orders. All prices F.O.B. Oshkosh

\section{Wild Rice}

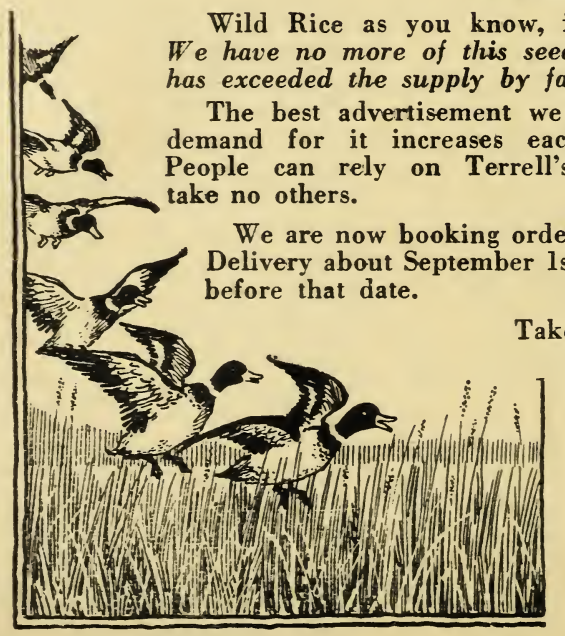

Take no substitute-Get

\section{TERRELL'S} Giant Wild Rice Seed

Prices for fall delivery$\$ 75.00$ per 100 tbs.

$80 \mathrm{c}$ per $\mathrm{tb}$.in lots of $25 \mathrm{tbs}$. or more.

$85 \mathrm{c}$ per th. in smaller lots.

95c per tit. prepaid

Order Early To Avoid Disappointment 


\section{CULTURAL DIRECTIONS}

These hardy outulour Ferns do not make satisfactory house plants; they will best in shade or half shady spots in the garden and mixed in between shrubs in fo dation planting on the east and north sides of buildings. Some of these, like the munda, Claytonjana, Lady and Sensitive Fern and Ostrich Fern will do reasonab well in considerable direct sunlight but will fade earlier than when planted in sha or half shade. They do best in light soil containing much vegetable matter or hum and covered with rotting wood shavings, peat or straw, which keep them from spro ing too early in the spring preventing a late night frost from killing the young fron

Hardy Ferns should be planted when dormant any time between Sept. 1st a July 1st. They prefer a settled foundation and cool feet, consequently they do bett the first year when planted in the fall. If late spring planting is follower by a hot summer the fronds are likely to dry up in the middle of the summer the first son unless artificial watering can be given in abundance.

SOILS-Do not apply fresh manure nor artificial or commercial fertilizer.

These roots are not immature light mail order plants, but strong well establish not less than 5 year old plants, with a lot of vitality stored up in their roots whi will keep them alive for a long time under adverse conditions. This refers especia to the Ostrich, the Osmundas, the Goldies and Lady Ferns.

\section{WE CAN FLRNISH THE FOLLOWIXG HARDY FERNS I'T :0C EACH FITE OF ONE VARIETY FOR \$1.50 \\ Prepaid by Parcel Post}

Adianthum Pedatum (Maidenhair fern), 12-1S inches.

Aspidium Acrosticoides (Dagger fern), 10-15 inches.

Aspidium Christatum (Chrested fern, evergreen), 10-1j inches.

Aspidium Christatum (rar. Clintoniana, evergreen), 15-25 inches.

Aspidium Goldiana (Goldies Wood fern), 25-35 inches.

Aspidium Thelypteris (Marsh Shield fern), 10-15 inches.

Asplenium Felix Fæmina (Lady fern), 15-35 inches.

Dicksonia Punctilobula (Hayscented fern), 12-18 inches.

Onoclea Sensibilis (Sensitive fern), 10-35 inches.

Onoclea Strutiopteris (Ostrich Plume fern), 25-50 inches.

Osmunda Cinnamomea (Cinnamon Colored fern), 20-40 inches.

Osmunda Claytoniana (Interrupted or Flowering fern), $20-35$ inches.

Osmunda Regalis (Poyal fern), 20-35 inches.

Thegopteris Dryopteris, $4-6$ inches.

Polypodium Vulgare (Rock fern), 5-12 inches.

Ferns give best effect in groups with five or more of one variety.

j0 Ferns, your selection, in any j varieties for $\$ 10.00$ by express not prepail.

We also offer the following special collections, carriage prepaid, for $\$ 5.00$ or ollt half for $\$ 3$. By express, not prepaid, each collection $\$ 4.00$, or any one-half $\$ 2.25$. all four collections, $\$ 4$ ferns in all, for $\$ 15.00$.

You can order by number and say one or one-half collection and we will make mistake. We have these ferns dormant almost up to July 1 st.

Vo. 1. General collection of the three varieties that have given universal satisfac tion under all conditions anywhere, 8 Ostrich Plume, 4 Osmunda Claytonians
8 Lady Ferns.

No. 2. Special for dry, shady places, 10 Dagger Fern, 6 Hayscented, 6 Claytonian Yo. 3. For moist, shady places, 4 Maiden Hair, 4 Christmas Fern, 4 Ostrich Plume
4 Cinnamon, 4 Lady Fern. No. 4. For wet ground, 4 Marsh Shield Fern, 10 Sensitive Fern, 6 Royal Fern.
Clintoniana.

We shall be pleased to quote you special prices in lots of one hundred, one thousan and ten thousand-not prepaid.

\section{TERRELL'S AQUATIC FARM OSHKOSH, WISCONSIN}




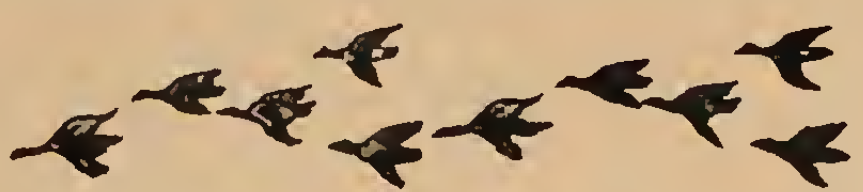

\section{MALLARDS! BLACK DUCKS:}

Wild Duck Millet

This plant is popularly known throughout the famous wildfowl resorts of the South, as "Wild Rice,"and is given about the same rank as a duck food, as the Wild Rice in the North. Mallards, Black Ducks and other Marsh Ducks love it.

Wild Duck Millet grows on damp lowlands, mud flats, or on the rich damp soil along the shore, just above the water's edge. The seed may be sown broadcast.

Plant Wild Duck Millet seed now using $40 \mathrm{tbs}$. per acre. It will mature furnishing abundant food for the wild ducks next fall. The seed is inexpensive, selling at $\$ 20$. per $100 \mathrm{lbs} ; \$ 3.00$ for 10 . (No quantity less than $10 \mathrm{fbs}$ sold.) Prices F. O. B. Oshkosh.

\section{WAPATO DUCK POTATO}

\section{EXCELLENT ATTRACTION FOR MALLARDS AND OTHER MARSH DUCKS!}

Mr. L. E. Selby of Pekin, Illinois, planted a large bed of Wapato one spring and a year or so later, wrote:

"The ducks can hardly be driven out of them after they once find the bed. The other day I was out at the club and the ducks were then setting on the ice waiting for the ice to melt so they could get at the Duck Potatoes that were left over last fall."

I told him that was fetching it pretty strong, and he then said he would take me up and show them to me. However, we have proven it to our own satisfaetion.

This is your last chance to get Wapato Duck Potato tubers for spring planting. Plant now to provide food for the wild ducks next fall. 1,200 tubers plant an acre.
3,000 tubers@\$33.00 per 1,1100
500 tubers@\$20.00
1,000 tubers@ $@ 35.00$
100 tubers@\$5.00

\section{CANVASBACKS: REDHEADS: Wild Celery}

All parts of the Wild Celery are eaten by the ducks, but Canvasbacks and Redheads prefer the tender roots and tubers produced by this plant.

Where Wild Celery does not grow naturally, it is a very easy matter to establish some fine beds by planting a thousand or two of these winter-buds this spring. 1,000 winterbuds will plant an acre. Plantings should be made soon as possible.

5,000 or more winter-buds @ $\$ 33.00$ per 1,000 500 winter-buds @ $\$ 22.00$

1,000 winter-buds@ @ $\$ 38.00$

100 winter-buds@\$5.00

\section{Sago Pond Plant}

When everything else fails, you can usually be sure of Sago Pond Plant proving successful. It grows under almost any condition, fresh or brackish, landlocked or running waters from one and one-half to six feet deep.

All kinds of ducks love it and feed on it from early until late fall, and in the North, only the freeze-up will drive them out.

We are shipping out Sago Pond Plant tubers for planting now. Five hundred or a thousand of these planted now, will insure you of more ducks in the future. This is the last call for spring planting.

1,000 tubers@\$60.00

500 tubers@\$35.00

100 tubers@\$7.50

Complete instructions for planting furnished with all orders. All prices F.O.B. Oshkosh

\section{Wild Rice}




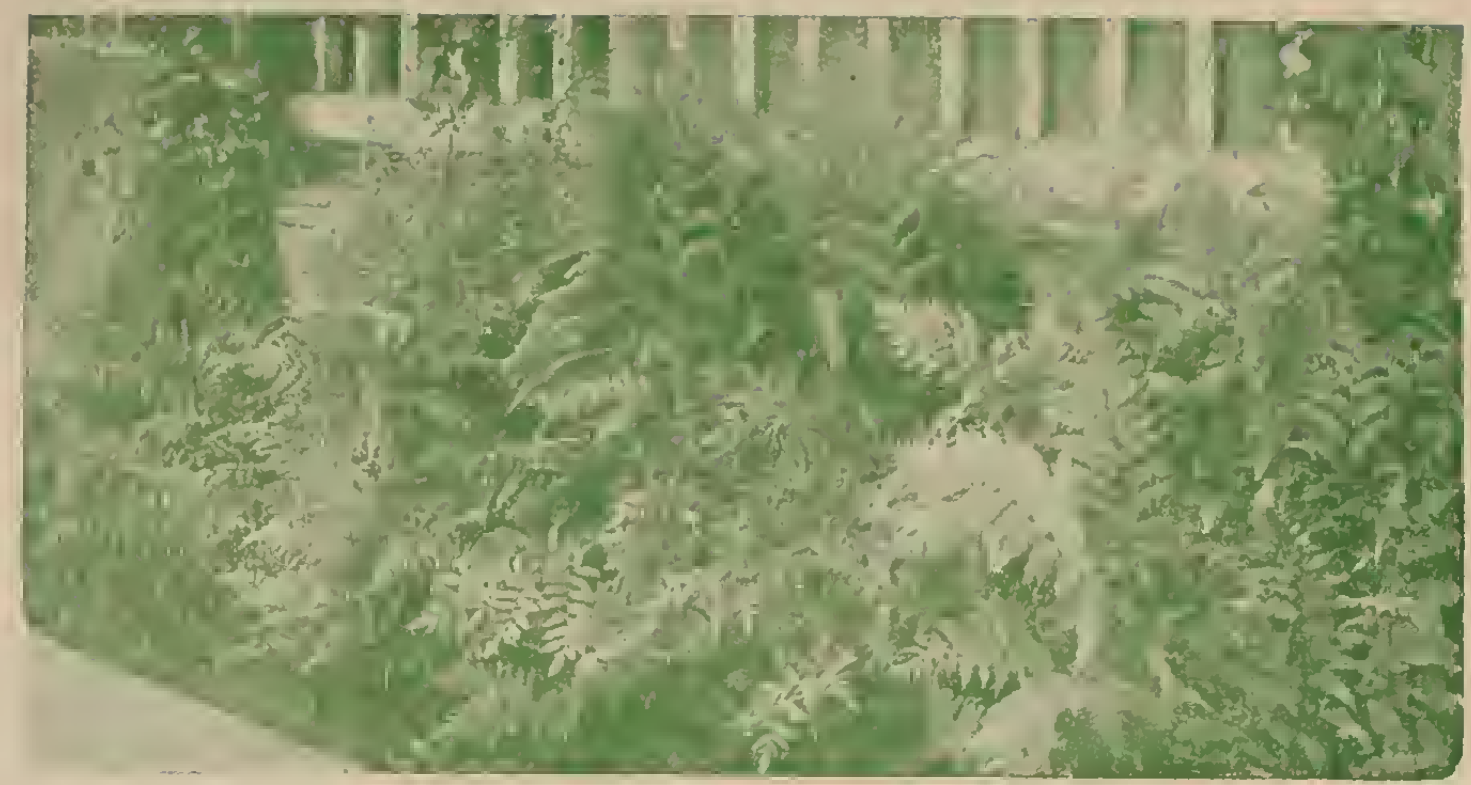

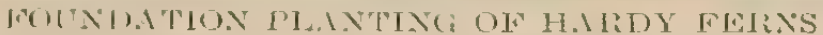

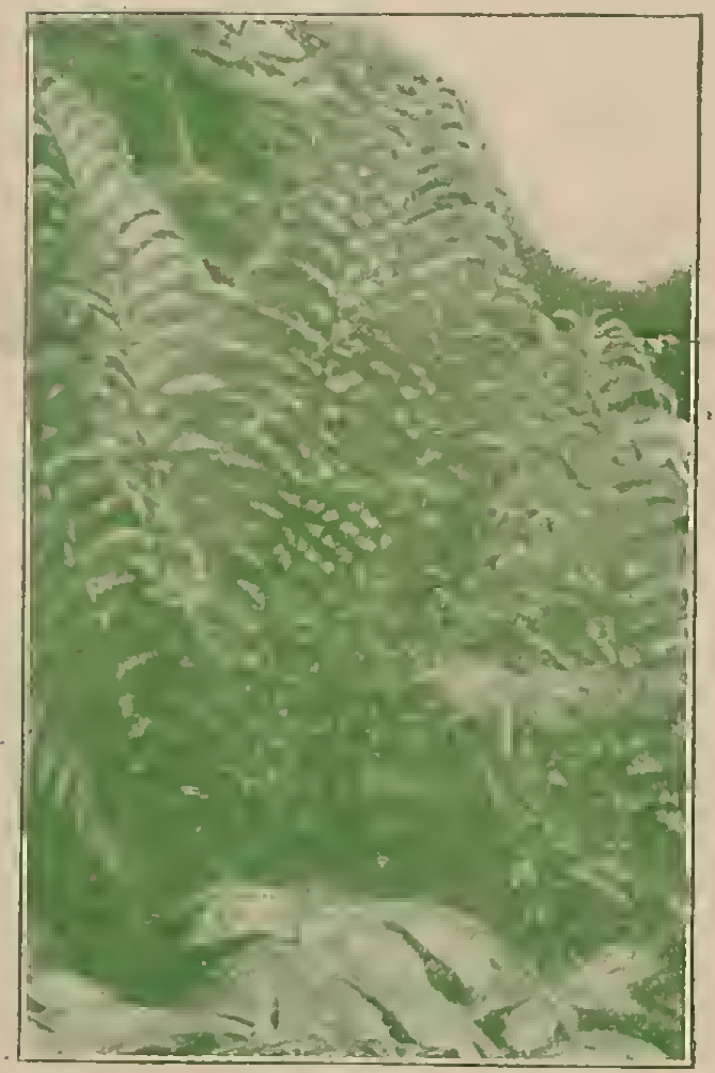

OSTRICH I'LUME FERN

\section{A FERN BED FOR ONLY \$5}

We Ofier Prepaid by Palcel Post for \$is 8 Ostrich Plume Ferus.

\section{I.anly Ferıs.}

4 Osmundas.

One-lialf assortment. 10 fcris, for $\$ 3.00$. One-fourth assortment, 5 ferns, for $\$ 1.75$. Any one fern for $50 \mathrm{c}$.

Hardy outdoor Ferns grow best in the shade or half shadc and will do well in the border. They are just the thing for that shady place around your house where most flowers will not do so well.

Of all the Hardy Ferns the Ostrich Plume, irlso called the Palm of the North, is perhaps the best as it grows the tallest and fastest of any Fern. It often has as many as fifteen fronds graccfully arranged, presenting an object more beautiful than many varieties of palms. The fronds under favorable conditions attain a length up to four feet.

Lady Fern is an extremely variable one, srowing in all sorts of situations from inw. moist woodlands and shaded stream banks to lry wools and bushy clearings, but to develop its best forms it wants partial shade and a reasomable amount of moisture in the spring. The Lady Fer'n is a distinct different type from the Ostrich and Osmunda.

The Interrupted Fern, known also as Claylons or Flowering Fern is considered one of the finest species for outdool cultivation. It is highly individual in form and bearing and is superbly graceful. This variety will also do well in open places and on rocky banks.

These three Ferns represent three distinct different types, not easily killed by ncglect or mistreatment. Planted in groups among shrubbery, each variety separate, they come perhaps nearer to imitate their natural haunts than by artificial ar ${ }^{\circ}$ angement in a formal garden. 


\section{CULTURAL DIRECTIONS}

These hardy outel(u) Ferns do not make satisfactory louse plants; they will do best in shade or lialf shady spots in the girlen and mixed in betwecn shrubs in foundation ylanting on the east and north sides of buildings. Some of these, like the Osmundi, C'aytomiana, Lady and Sensitive Fern and Ostrich Ferm will do reasonably well in cousildrable dircct sunlight but will fade earlier than when planted in shade (1) half shade. They do best in light soil coutaining much vegetable matter ol humus and corered wilh rotting wood shavings, peat or straw, which keep them from sprouting too early in the spring preventing a late night frost from lilling the young fronds.

Hally Ferns should be planted when dormant any time between Sept. 1st and July 1st. Thay prefer a settled foundation and cool fect, consequently they (lo better the first year when planted in the fall. If late spring planting is followed by a dry hot summel the frouls are likely to (lyy up in the middle of the summer the first senson unless allificial watering can be given in abundance.

SOILS-Do not apply fresh manure nor artificial or commercial fertili\%cr.

These roots are not immaturc light mail order plants, but strong well establishel, lot less than "5 year old plants, with a lot of vitality stored up in theil roots which will keep them alive for a long time under adverse conditions. This refers esuecially to the Ostrich, the Osmundas, the Golaies and Lady Ferns.

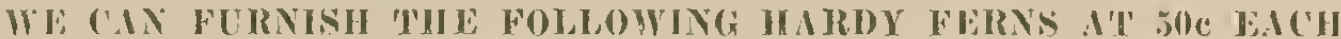 FIVE OF ONE, VARIETY FOR \$1.50 \\ J'repaid by l'areel l'ost}

Alianthum Perlatum (Maidenhair ferm), 12-1s inches.

Aspidium Acrosticoides (Dagger ferre, $10-15$ inches.

Aspidium Christatum (Chrested fern, evergleen), 10-15 inches.

Aspidium Christatum (var. Clintoniana, evergrecn), 15-25 inches.

Aspidium Goldiana (Goldies Wood fern), 25-35 inehes.

Aspidium Thelypteris (Marsh Shield fern), 10-15 inches.

Asplenim Felix Frumina (Larly fern), 15-35 inches.

Dicksonia Punctilobula (Hayscented fern), $12-18$ inches.

Onoclea Sensibilis (Sensitive fern), $10-35$ inches.

Onoclea Strutiopteris (Ostrich Plume fern), 25-50 inches.

Osmunda Cinnamomca (Cimnamon Colored fern), $20-40$ inches.

Osmunda Claytoniana (Interrupted or Flowering fern), 20 - 35 inclues.

Osmunda Regalis (Royal fern), 20-35 inehes.

Thegopteris Dryoptcris, $4-6$ inches.

Polypodium Vulgare (Rock fern), $5-12$ inches.

Fcrins give best effect in groups with five or more of one variety.

.) Felus, you selection, in any 5 ralietles for \$10.00 by expless not prejaid.

We also offer the following special eollections, carringe prepilid, for $\$ 5.0000^{\circ}$ onehalf for $\$ 3$. By cxpress, not prepaid, eaeh colleetion $\$ 4.00$, ol ally onc-half $\$ 2.25$. () all foul colleetions, $\$ 4$ ferms in all, for $\$ 15.00$.

You can order by umber and say one or onc-half collection and we will make mo mislake. We have these ferms dormant almost up to July 1st.

Io. 1. General collection of the three varieties that have given universal satisfaction under all comblitions anywhere, 8 Ostrich Plume, $t$ Osmunda Clirvtonianis. 8 Ladly Felns.

Vo. 2. Special for (lyy, shady places, 10 Dagger Fern, 6 Hnyscented, 6 Claytonianil.

Vo. 3. For moist, shady places, 4 Maiden Hair, 4 Christmas Fern, 4 Ostrieh Plume, 4 Cinnamon, 4 Lady Feln.

No. 4. For wet ground, 4 Marsh Shield Ferm, 10 Sensitive Ferm, 6 Royal Ferm, 4 Clintoniana.

IVe shall be pleased to quote you special priees in lots of one hundrerl, one tlumsinc and ten thousand-not prepaid.

\section{TERRELL'S AQUATIC FARM




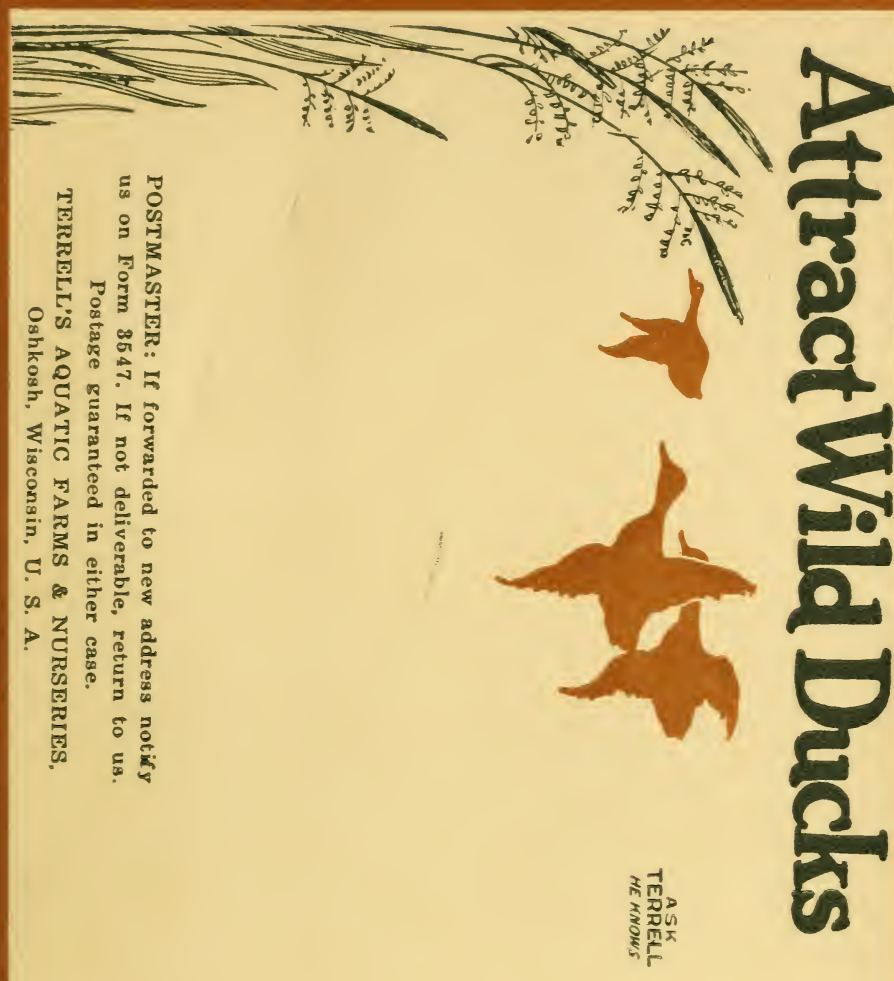




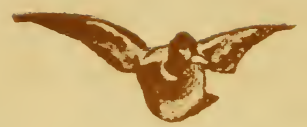

\section{Guarantee, Terms, Shipments, Etc.}

Most seedsmen make no guarantee of their seeds. However we furnish only seed of the highest germination, and when planted under suitable conditions, we do not expect that any one will have cause for complaint. We make the following buarantee:

If any of our planting materials should fail to produce what the purchaser considers a satisfactory growth after giving the planting sufficient time to establish itself, we GUARANTEE to replace it at half-price or send an equal value at half-price of other planting material selected from our current price list.

SHIPMENTS of these seeds except Bur Reed and Duck Bait should be made by Express, so they will reach their des. tination quickly and in the best condition for planting. Second Class Rates, which are about $25 \%$ lower than first class, are secured on these seeds and dormant roots or tubers. If you have no Express Office we can ship by Parcel Post if desired. If you wish shipment to be sent by Parcel Post or Prepaid Express send 12c per pound to cover transportation charges. (This does not apply to foreign countries except Canada).

\section{PRICES HEREIN EFFECTIVE SEPTEMBER 15, 1929.}

PRICES quoted are in terms of American money and do not include payment of transportation charges unless so stated. Terms: C. 0 . D. or $2 \%$ discount for cash with order.

FOREIGN PRICES., Prices on materials shipped to foreign countries other than to Canada, $25 \%$ higher than quoted, to cover special packing, customs papers and arrangements neces. sary on such shipments.

REFERENCES - City National Bank, First National Bank, Chamber of Commerce, all of Oshkosh, Wisconsin; R. G. Dun \& Co., Reference Book; Leading Outdoor Magazines; State Fish and Game Commissioners of Wisconsin, Montana, Iowa, Pennsylvania and Indiana; American Game Protective Association, Woolworth Building, New York City; National Association of Audubon Societies, 1974 Broadway, New York City; Glen C. Leach, Bureau of Fisheries, Washington, D. C.; Izaak Walton League, 549 W. Randolph Street, Chicago, III.

\section{Address All Communications to}

CLYDE B. TERRELL or

\section{TERRELL'S AQUATIC FARMS AND NURSERIES}

Oshkosh, Wisconsin, U. S. A. 


\section{ORDER BLANK \\ TERRELL'S Aquatic Farm and Nurseries}

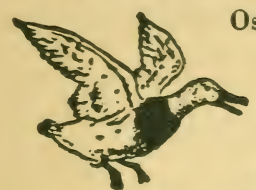

First Come-First Served

Order Early to Avoid Disappointment

MORE FOOD, MORE BIRDS, MORE FISH

Ship to

Name

Address

Post Office if different from shipping point.

lbs. Giant Wild Rice Seed, 1000 lbs. or more $48 \mathrm{c} \mathrm{lb.;} 100 \mathrm{lbs}$. or more $50 \mathrm{c} \mathrm{lb}$; $30 \mathrm{lbs}$. or 1

bu. \$17.; smaller lots $80 \mathrm{c}$ lb.; prepaid 92c lb. \$.........

Bu. Muskgrass (Chara) Plants with 'seed. spores' $\$ 6$ bu.; 1 bu. Free with every 5 bu. \$......... lbs. Natural Duck Bait, 100 lbs., $\$ 10 ; 500$ lbs. or more $9 \mathrm{c} \mathrm{lb}$.

........... (List other items below)

DISCOUNT-2\% discount for cash with order.

Ordered by

Amount enclosed

$\$ \ldots \ldots \ldots$

Name

Address

Add 12c per lb. if you want transportation charges prepaid. 


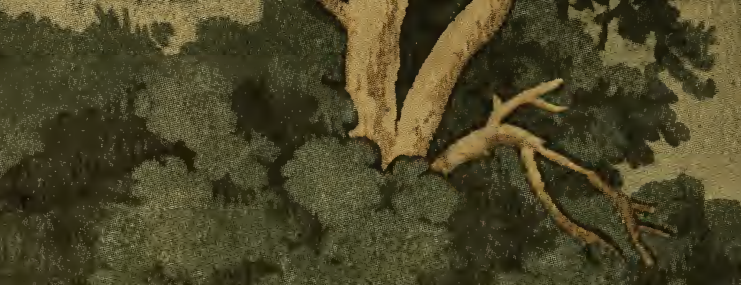

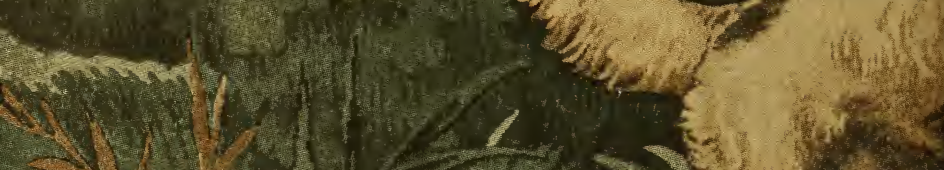

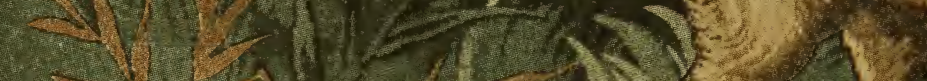

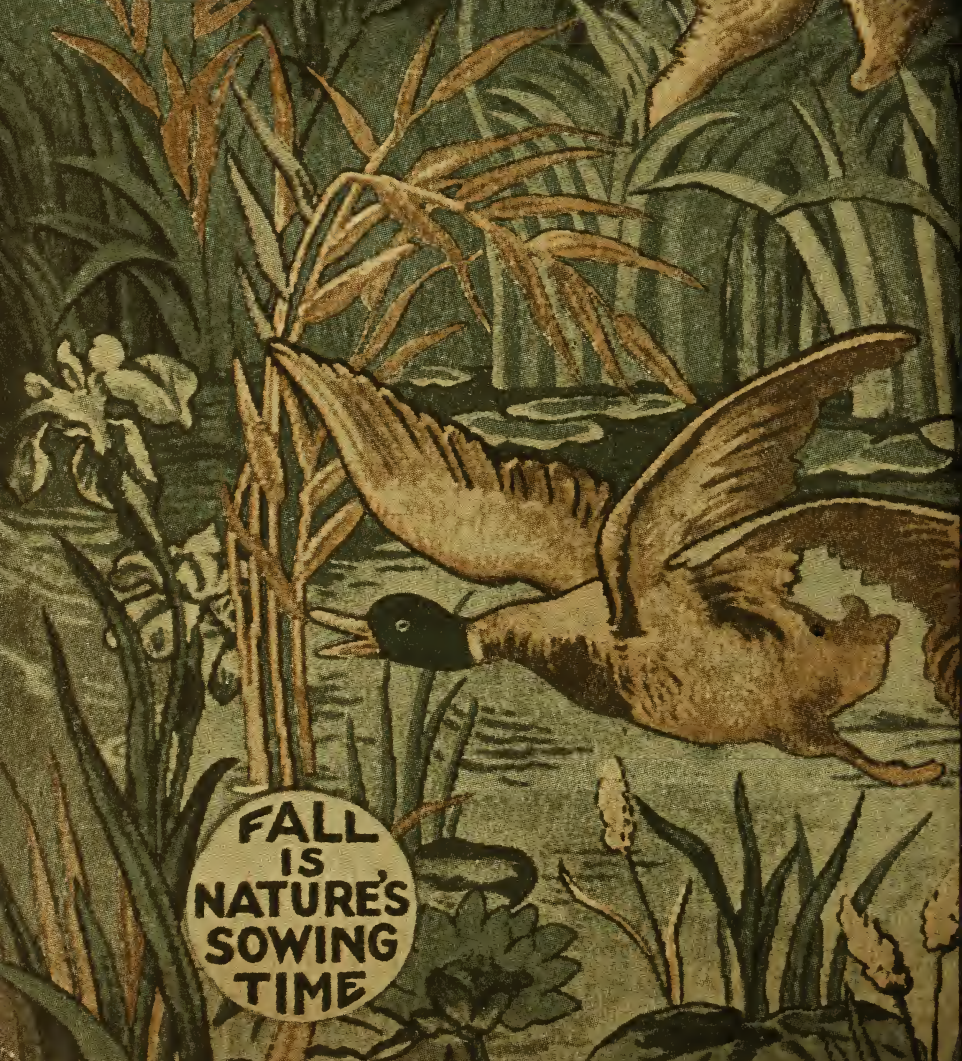

